Review

\title{
Exosomal RNAs: Novel Potential Biomarkers for Diseases-A Review
}

\author{
Jian Wang ${ }^{1} \mathbb{D}$, Bing-Lin Yue ${ }^{2}$, Yong-Zhen Huang ${ }^{1}{ }^{\mathbb{D}}$, Xian-Yong Lan $^{1}$, Wu-Jun Liu ${ }^{3, *}$ and Hong Chen ${ }^{1,3, *}$ \\ 1 Key Laboratory of Animal Genetics, Breeding and Reproduction of Shaanxi Province, College of Animal \\ Science and Technology, Northwest A\&F University, Yangling 712100, China; wangjsci@126.com (J.W.); \\ hyzsci@nwafu.edu.cn (Y.-Z.H.); lanxianyong79@nwsuaf.edu.cn (X.-Y.L.) \\ 2 Key Laboratory of Qinghai-Tibetan Plateau Animal Genetic Resource Reservation and Utilization, \\ Sichuan Province and Ministry of Education, Southwest Minzu University, Chengdu 610225, China; \\ yuebinglin123@163.com \\ 3 College of Animal Science, Xinjiang Agricultural University, Urumqi 830052, China \\ * Correspondence: wujunliu1026@xjau.edu.cn (W.-J.L.); chenhong1955@nwsuaf.edu.cn (H.C.)
}

Citation: Wang, J.; Yue, B.-L.; Huang, Y.-Z.; Lan, X.-Y.; Liu, W.-J.; Chen, H. Exosomal RNAs: Novel Potential Biomarkers for Diseases-A Review. Int. J. Mol. Sci. 2022, 23, 2461. https://doi.org/10.3390/ ijms23052461

Academic Editor:

Abdelnaby Khalyfa

Received: 24 January 2022

Accepted: 18 February 2022

Published: 23 February 2022

Publisher's Note: MDPI stays neutral with regard to jurisdictional claims in published maps and institutional affiliations.

Copyright: (C) 2022 by the authors. Licensee MDPI, Basel, Switzerland. This article is an open access article distributed under the terms and conditions of the Creative Commons Attribution (CC BY) license (https:// creativecommons.org/licenses/by/ $4.0 /)$.

\begin{abstract}
Exosomes are a subset of nano-sized extracellular vesicles originating from endosomes. Exosomes mediate cell-to-cell communication with their cargos, which includes mRNAs, miRNAs, lncRNAs, and circRNAs. Exosomal RNAs have cell specificity and reflect the conditions of their donor cells. Notably, their detection in biofluids can be used as a diagnostic marker for various diseases. Exosomal RNAs are ideal biomarkers because their surrounding membranes confer stability and they are detectable in almost all biofluids, which helps to reduce trauma and avoid invasive examinations. However, knowledge of exosomal biomarkers remains scarce. The present review summarizes the biogenesis, secretion, and uptake of exosomes, the current researches exploring exosomal mRNAs, miRNAs, lncRNAs, and circRNAs as potential biomarkers for the diagnosis of human diseases, as well as recent techniques of exosome isolation.
\end{abstract}

Keywords: exosome; biomarker; human disease; mRNA; miRNA; lncRNA; circRNA; isolation techniques

\section{Introduction}

Disease diagnosis is a key step in clinical practice. The detection of soluble biomarkers from biofluids became a critical method in the early diagnosis of diseases. Exosomes received increased attention due to their wide distribution in body fluids and their ability to reflect physiological and pathological conditions.

Exosomes are a type of lipid membrane-bound extracellular vesicle with an average size of $100 \mathrm{~nm}$ (ranging from 40 to $160 \mathrm{~nm}$ ) [1]. Most cell types, including mesenchymal stem cells, endothelial cells, myoblasts, and adipocytes, can release exosomes of different sizes, compositions, and functions. More importantly, exosomes are widely present in almost all biofluids, including cell supernatant, blood, plasma, saliva, urine, serum, and breast milk [2-6]. Exosomal contents, including RNAs, DNAs, proteins, and lipids, can participate in physiological processes such as intercellular communication and material transport [7]. There is particularly strong evidence of exosomal RNAs regulating gene expression and function in recipient cells. Exosomal RNAs can affect normal physiological metabolic activities and participate in the development of various diseases, including tumor growth, neurodegenerative disease, and metabolic syndrome [7-10]. Exosomal RNAs are a promising source of diagnostic biomarkers for human diseases [11,12]. In this review, we focus on recent studies exploring exosomal mRNAs and ncRNAs (miRNAs, lncRNAs, and circRNAs) as biomarkers for human diseases. 


\section{Biogenesis of Exosomes}

Exosomes are extracellular vesicles of endosomal origin. First, the plasma membrane invaginates to form an early endosome. This endocytosis process can encapsulate extracellular soluble proteins, and the early endosome membrane can contain cell-surface proteins [13]. Then, the early endosomes give rise to late endosomes, invaginate, and form intraluminal vesicles (ILVs) [13]. Here, the late-stage endosomal structures containing dozens of ILVs are typically known as multivesicular bodies (MVBs), which are partly delivered to lysosomes for degradation or fusion with the plasma membrane to release the contained ILVs as exosomes (Figure 1). Specifically, the formation of the endosomal sorting complexes required for transport (ESCRT) is essential for both the synthesis and secretion of exosomes. The ESCRTs consist of four complexes (ESCRT-0, I, II, and III) and related proteins (VPS4, TSG101, and ALIX) [14,15]. ESCRT-0 classifies ubiquitin cargo proteins into lipid domains, whereas ESCRT-I and ESCRT-II are responsible for deforming the membrane to format a stable membrane neck [14]. ESCRT-III participates in membrane deformation and fission, such as promoting ILV budding [16,17]. The recruitment of the VPS4 complex into ESCRT-III results in vesicle neck dissection and the dissociation and recycling of the ESCRT-III complex [18]. TSG101 is connected to the release of exosomes, and the activation of ALIX protein could recruit ESCRT-III proteins to endosomes [16,19]. Additionally, numerous studies showed that exosome synthesis and cargo loading involve an ESCRT-independent pathway using lipids and associated proteins [20-22] (Figure 1).

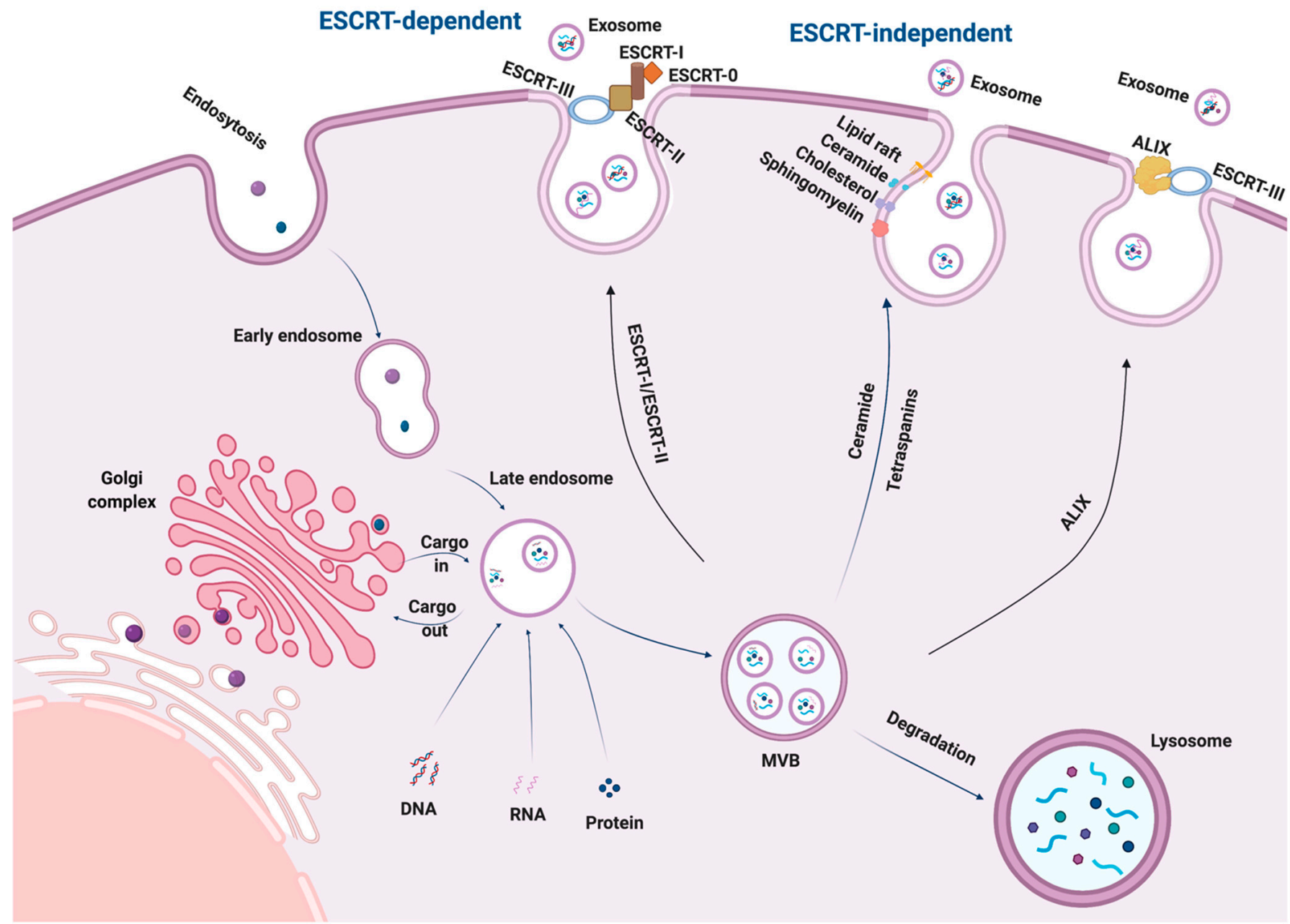

Figure 1. Biogenesis of exosomes. 
RNA loading into exosomes appears to be lipid-mediated and depends on specific self-organizing lipids and cargo domains. Specific nucleotide sequences have enhanced affinity for the phospholipid bilayer, including lipid rafts, hydrophobic modifications, or sphingosine [23]. Lipid rafts are highly enriched in cholesterol, sphingolipids, and glycosylphosphatidylinositol-anchored proteins, and their binding to proteins or other molecules might promote their secretion through exosomes [24]. Additionally, the presence of ceramide, lysophosphatidic, and glycosphingolipid molecules on the limiting membrane causes a spontaneous budding process that results in the formation of ILVs [25]. Meanwhile, ceramide may be transformed to sphingosine and sphingosine-1-phosphate (S1P) by the enzymes ceramide kinase and ceramidase, while the subsequent activation of S1P receptors on the limiting membrane facilitates the mediation of tetraspanin sorting into ILVs [26,27]. The tetraspanin superfamily consists of cell surface-associated membrane proteins characterized by transmembrane domains and organizes the membrane microdomains known as tetraspanin-enriched microdomains, which contain abundant transmembrane and cytoplasmic signal proteins [28]. Notably, although it was reported that the absence of ESCRT machinery did not prevent the production of MVBs in mammalian cells, it may bring about the sorting of cargo into ILVs and variation in the quantity and size of ILVs. This indicates that exosome biogenesis may be a coordinated process involving both ESCRT-dependent and -independent pathways [29].

\section{Secretion and Uptake of Exosomes}

The release of exosomes into the extracellular space depends on the transport of secretory MVBs and the fusion of the cell membrane after the inward budding of ILVs, which requires several key factors including the cytoskeleton (microtubules and microfilaments), molecular movements (mediated by kinetin and kinesin), molecular switches (small GTPase), and membrane fusion devices (soluble NSF attachment protein receptor [SNARE] complexes) [30]. During secretory MVB transport, the MVB moves along the microtubule cytoskeleton-a process that requires molecular motors for directed transport [31,32]. Microtubules and their associated molecular motors showed obvious polarity distribution in cells and were combined with the MVB. The MVB and plasma membrane were fused by Rab and its effector. Rab GTPase is an important factor, with more than 70 subtypes on the membrane surface involved in the regulation of vesicular functions such as budding, movement, and fusion [33]. Although the details of the fusion process remain elusive, the SNARE protein family was widely accepted as the core machinery for membrane fusion. This protein family includes vesicle SNARE (v-SNARE), which forms a complex with the homologous target SNARE (t-SNARE). Notably, this complex drives the fusion of two membranes in a zipped manner $[34,35]$. Through this process, MVBs fuse with the plasma membrane and release the exosomes into the extracellular space.

Signals from exosomes are generally transmitted to receptor cells through three different mechanisms: endocytosis, direct membrane fusion, or receptor-ligand interaction. Endocytosis is the primary method of exosome uptake and can be mediated by grid proteins, caveolae, or lipid rafts depending on the specific receptor cell type [36]. During endocytosis, exosomes may subsequently merge into endosomes or be transferred to lysosomes for degradation [37]. Additionally, the exosomal membrane can fuse directly with the plasma membrane of the receptor cell and release its contents, or bind to homologous receptors on the receptor cell membrane to subsequently trigger a cascade of intracellular signal transduction reactions [38].

\section{Exosomal RNAs}

\subsection{Exosomal mRNAs}

Exosomal mRNAs are important regulators of cellular biological processes. Exosomal mRNAs were first identified in mouse MC $/ 9$ and human HMC-1 cell lines using microarray analysis. Interestingly, exosomal mRNAs from mouse mast cells could be transferred into human mast cell lines, indicating that exosomes are effective vessels for the delivery of 
mRNA to other cells. It was further discovered that mRNAs were selectively taken up into exosomes because 270 transcripts were only detected in exosomes other than the donor cells (MC/9). Additionally, exosomal mRNAs were translated into functional proteins in the recipient cells, suggesting that exosomal mRNAs retain their function in recipient cells. These results demonstrate that exosomal mRNAs are critical mediators of intercellular communications [2].

Exosomal mRNAs also have advantages as biomarkers. First, exosomal mRNA can reflect the conditions of donor cells and are easy to detect since some exosomes (e.g., blood exosomes) circulate throughout the entire body [39]. In addition, the membrane of the exosome can protect exosomal mRNA from digestion by RNases [40]. For example, urinary exosomal mRNAs can remain stable for as long as two weeks at $4{ }^{\circ} \mathrm{C}$ [41]. Finally, exosomal mRNAs can affect the function of recipient cells more directly than exosomal ncRNAs since they can be translated into proteins in recipient cells.

Exosomal mRNAs are considered as a critical indicator of cancers. Previous studies reported that tumor cells can express tumor-specific mRNAs or change the expression levels of normal exosomal mRNAs. For example, in glioblastoma, epidermal growth factor receptor (EGFR) is expressed by the tumor-specific mRNA EGFRvIII, which was recommended as a diagnostic biomarker for glioblastoma [42]. As another example, telomerase is considered a hallmark of cancer [43]. Human telomerase reverse transcriptase ( $h T E R T)$ is generally not expressed in healthy humans. However, $h T E R T$ is detectable in multiple cancers, such as acute myelocytic leukemia, Burkitt lymphoma, and chronic lymphocytic leukemia, indicating that serum exosomal $h T E R T$ mRNA may be a potential pan-cancer biomarker [44]. Additionally, serum exosomal heterogeneous nuclear ribonucleoprotein H1 (hnRNPH1) mRNA levels in hepatocellular carcinoma (HCC) patients were significantly higher than those in control groups. Thus, exosomal $h n R N P H 1$ was suggested as a potential biomarker for HCC diagnosis [45].

Exosomal mRNAs were also suggested as biomarkers for diagnosing other diseases, such as those related to the human central nervous system and urinary system. A study including 20 older healthy adult subjects ( $\geq 65$ years) and 20 younger healthy adult subjects (21-45 years) indicated that amyloid- $\beta 1-42$ peptide $(A \beta)$-the main component of the amyloid plaques found in the brains of patients with Alzheimer's disease [46] stimulated the release of exosomal cytokine mRNAs via macrophages and CD4 memory T-cells, indicating that exosomal cytokine mRNAs could potentially act as diagnostic biomarkers for Alzheimer's disease [47]. Furthermore, Lv et al. suggested the urinary exosomal mRNA CD2 associated protein $(C D 2 A P)$ as a biomarker for the diagnosis of kidney disease since a decrease in its expression level reflects the severity of tubulointerstitial fibrosis and glomerulosclerosis [48].

Exosomal mRNAs can also be used as biomarkers for the evaluation of drug resistance., which is currently one of the major challenges in cancer therapy. Shao et al. analyzed the exosomal mRNAs in the serum of 32 individuals (17 glioblastoma multiforme patients and 15 healthy individuals) and found that the exosomal O-6-methylguanine-DNA methyltransferase (MGMT) and N-methylpurine DNA glycosylase (APNG) mRNA levels were correlated with the levels of temozolomide resistance and the treatment efficacy in glioblastoma multiforme patients [49].

Based on studies of intracellular mRNAs, two successful commercial kits use urinary exosomal mRNAs (SAM pointed domain-containing ETS transcription factor (SPDEF) and ETS transcription factor (ERG)) and plasma exosomal mRNA (echinoderm microtubuleassociated protein-like 4-anaplastic lymphoma kinase (EML4-ALK) fusion transcripts) to detect prostate cancer and nonsmall-cell lung cancer, respectively [50-52], which demonstrates the functionality of exosomal mRNAs as biomarkers.

Some examples of exosomal mRNAs with the potential to be used as biomarkers for disease diagnosis are summarized in Table 1. 
Table 1. Summary of exosomal mRNAs as potential disease biomarkers.

\begin{tabular}{|c|c|c|c|}
\hline Exosome Sources & Diseases & Potential Biomarkers (mRNA) & References \\
\hline Serum \& glioblastoma CCM & Glioblastoma & EGFRvIII & [42] \\
\hline Urine & $\begin{array}{c}\text { Tubulointerstitial fibrosis \& } \\
\text { glomerular sclerosis }\end{array}$ & $C D 2 A P$ & [48] \\
\hline Serum \& GBM CCM & Temozolomide resistance in GBM & $M G M T \& A P N G$ & [49] \\
\hline Urine & Prostate cancer & $E R G$, and $S P D E F$ & [50] \\
\hline U87 \& A172 CCM & $\begin{array}{l}\text { Temozolomide chemoresistance } \\
\text { in glioblastoma }\end{array}$ & PTPRZ1-MET & [53] \\
\hline Serum & Hepatocellular carcinoma & hnRNPH1 & [45] \\
\hline Serum & Docetaxel resistance in prostate cancer & $C D 44 v 8-10$ & [54] \\
\hline HFF CCM & Toxoplasma-infected HFFs & $R A B-13, E E F 1 A 1, T M S B 4 X \& L L P H$ & {$[55]$} \\
\hline Serum & Colorectal cancer & KRAS mutation \& BRAF mutation & [56] \\
\hline Serum & Gastric cancer & $M T 1-M M P$ & [57] \\
\hline Plasma & $\begin{array}{l}\text { Resistance to hormonal therapy in } \\
\text { prostate cancer }\end{array}$ & $A R-V 7$ & {$[58]$} \\
\hline Serum & Pancreatic ductal adenocarcinoma & WASF2, ARF6, SNORA74A \& SNORA25 & [59] \\
\hline Serum \& CCM & Acute lymphoblastic leukemia & DNMT1 & [60] \\
\hline
\end{tabular}

CCM: cell culture media; GBM: human glioblastoma multiforme; HFF: human foreskin fibroblasts; EGFRvIII epidermal growth factor receptor variant III, CD2AP: CD2 associated protein; MGMT: O-6-methylguanine-DNA methyltransferase; APNG: N-methylpurine DNA glycosylase; ERG: ETS transcription factor; SPDEF: SAM pointed domain containing ETS transcription factor, PTPRZ1: protein tyrosine phosphatase receptor type Z1; MET: MET proto-oncogene, receptor tyrosine kinase; hnRNPH1: heterogeneous nuclear ribonucleoprotein $\mathrm{H} 1$; CD44v8-10: isoform of cluster of differentiation 44 variant, and contains the variant exons 13-15 (v8-v10); RAB-13: RAB13, member RAS oncogene family; EEF1A1: eukaryotic translation elongation factor 1 alpha 1, TMSB4X: thymosin beta 4 X-linked; LLPH: LLP homolog, long-term synaptic facilitation factor, KRAS: KRAS proto-oncogene, GTPase; BRAF: B-raf proto-oncogene, serine/threonine kinase; MT1-MMP: mmbrane type-1 matrix metalloproteinase; AR-V7: androgen receptor variant 7; WASF2: WASP family member 2; ARF6: ADP ribosylation factor 6; SNORA74A: small nucleolar RNA, H/ACA box 74A; SNORA25: small nucleolar RNA, H/ACA box 25; DNMT1: DNA-methyltransferase 1.

\subsection{Exosomal miRNAs}

MiRNAs, a class of small noncoding RNAs with a length of $\sim 22 \mathrm{nt}$, play a principal role in the regulation of gene expression at the post-transcriptional level [61]. MiRNAs mainly function by binding to the $3^{\prime}$ untranslated region ( $3^{\prime}$-UTR) of target mRNAs and inducing cleavage or reducing translation [62]. Both cellular miRNAs and exosomal miRNAs are involved in various biological activities, including cancer progression, immune responses, and cell cycle progression [61].

Exosomal miRNAs were proposed as potential biomarkers for diagnosing and predicting diseases. This primarily relies on their ability to reflect the internal conditions of cells, including physiological and pathological conditions [63]. In addition, miRNAs are the most abundant RNA molecules in exosomes, which makes their detection easier than that of other types of exosomal RNA [64]. Lastly, exosomal miRNAs show improved stability due to the protection afforded by their encapsulating membranes. It was observed that exosomal miRNAs can remain stable for five years when stored at $-20^{\circ} \mathrm{C}$ or for 14 days at $4{ }^{\circ} \mathrm{C}$, with this stability being unaffected by repeated freezing and thawing [65]. These characteristics help increase the sensitivity of exosomal miRNA-based biomarkers. This is critical as limited sensitivity results in low detectability.

Recent studies identified some exosomal miRNAs with great potential for diagnosing cancers. Exosomes derived from cancer cells might affect the function of normal cells via miRNAs and could be an essential factor driving cancer metastasis. In a study on brain cancer, human and mouse tumor cells were observed to stop expressing phosphatase and tensin homolog (PTEN) - an important tumor suppressor-after dissemination to the brain due to inhibition mediated by exosomal miR-19 that was secreted by astrocytes, which indicates that exosomal miR-19 might be a suitable biomarker for diagnosing brain cancer metastasis [66]. Another study showed that colorectal cancer cells promoted the M2 pole of macrophages by transferring a set of miRNAs (miR-25-3p, miR-130b-3p, and miR-425-5p) through exosomes in response to stromal cell-derived factor $1 / \mathrm{C}-\mathrm{X}-\mathrm{C}$ chemokine receptor 
type 4 (CXCL12/CXCR4) activation through the PTEN/PI3K/Akt pathway, which enhanced the liver metastasis of colorectal cancer in vitro and in vivo [67].

Exosomal miRNAs can serve as biomarkers for diagnosing diseases other than cancer. Macrophages are critical for the maintenance of metabolic homeostasis, and their exosomal miRNAs are closely related to various metabolic-related diseases, such as diabetes and obesity [68]. For instance, exosomal miR-690 binds to the $3^{\prime}$-UTR of the NAD kinase (NADK) mRNA, which is responsible for regulating insulin signaling and macrophage inflammation, to enhance insulin sensitivity [69]. Exosomal miRNAs could also reflect the viral infection of cells. One well-known example is the Epstein-Barr virus (EBV), the first human virus that was found to encode miRNAs [70]. B cells infected with EBV secrete exosomes containing EBV-miRNAs, which affect gene expression in the recipient cells [71].

Other recent examples of exosomal miRNAs with the potential to be used as biomarkers for disease diagnosis are summarized in Table 2.

\subsection{Exosomal $\operatorname{lnc} R N A s$}

Long noncoding RNAs (lncRNAs) are a type of noncoding RNA longer than 200 nt [99]. LncRNAs are involved in the regulation of gene expression in diverse manners at multiple levels, such as gene transcription control, chromatin structure modulation, RNA splicing regulation, miRNA sponging, and RNA-binding protein interaction [100].

Typically, exosomal lncRNAs display strong tissue specificity and poor conservation, and the expression levels of exosomal lncRNAs can indicate the health conditions affecting tissues and cells, making them suitable for use as biomarkers [101,102]. Additionally, the large number of tissue- and cell-specific lncRNAs provides many options for diagnostic biomarkers.

Exosomal lncRNAs were suggested as biomarkers to diagnose diseases. For example, lncRNA prostate cancer antigen 3 ( $\operatorname{lnc} P C A 3)$ - found in urinary exosomes-was approved as a biomarker to diagnose human prostate cancer by the US Food and Drug Administration. Exosomal lncPCA3 shows a much higher expression level in prostate cancer cells than in inflamed or normal prostate tissue (up to 70- to 100-fold), making lncPCA3 an efficient biomarker for diagnosing prostate cancer [103-105]. Another example is H19, a well-known oncogenic lncRNA found in serum exosomes that was significantly upregulated in bladder cancer patients when compared to that of healthy individuals, which highlights its potential use as a biomarker for bladder cancer $[106,107]$.

Compared to exosomal miRNA, the study of exosomal lncRNA is in its infancy. According to GENCODE, there are more than 16,000 lncRNA genes in the human genome, which are estimated to produce more than 10,000 lncRNA transcripts, indicating a considerable candidate pool of potential diagnostic biomarkers [108,109].

Recent examples of exosomal lncRNAs that are potential diagnostic biomarkers are summarized in Table 3. 
Table 2. Summary of exosomal miRNAs as potential disease biomarkers.

\begin{tabular}{|c|c|c|c|c|c|}
\hline Exosome Sources & Potential Biomarkers & Diseases & Target Genes/Pathways & Effects & References \\
\hline Serum & $\operatorname{miR}-193 b$ & $\mathrm{AD}$ & $A P P$ & Inhibits AD development & [72] \\
\hline Glioblastoma stem CCM & $\operatorname{miR}-9$ & $\begin{array}{l}\text { Antiangiogenic therapy } \\
\text { for glioblastoma }\end{array}$ & RGS5, SOX7 \& ABCB1 & Promotes angiogenesis & [73] \\
\hline Plasma & $m i R-146 a$ & Heart failure & $\begin{array}{l}\text { IRAK-1, TRAF6, NOX-4 } \\
\quad \text { SMAD4 \& TGF- } \beta\end{array}$ & $\begin{array}{l}\text { Promotes the proliferation and inhibit the } \\
\text { apoptosis of cardiomyocytes }\end{array}$ & [74] \\
\hline Plasma & $m i R-21 \& m i R-181 a-5 p$ & Thyroid cancer & $\mathrm{N} / \mathrm{A}$ & $\begin{array}{c}\text { Distinguishes between follicular and papillary } \\
\text { thyroid cancer }\end{array}$ & [75] \\
\hline HCT116 CCM \& serum & $\begin{array}{l}m i R-25, m i R-130 b, \text { and } \\
m i R-425\end{array}$ & Colorectal cancer & PTEN/PI3K/AKT pathway & $\begin{array}{l}\text { Promotes the liver metastasis of } \\
\text { colorectal cancer }\end{array}$ & [67] \\
\hline CCM \& serum & $m i R-1247-3 p$ & Liver cancer & B4GALT3 & Promotes the lung metastasis of liver cancer & [76] \\
\hline A2780 CCM & $m i R-223$ & Epithelial ovarian cancer & PTEN/PI3K/AKT pathway & Promotes chemoresistance & [77] \\
\hline Multiple sources & $m i R-21$ & Various cancers & Multiple targets & Promotes cancer development & [78-82] \\
\hline Microglia culture media & miRNA-137 & Ischemic brain injury & NOTCH1 & Promotes neuroprotection & [83] \\
\hline Plasma & $m i R-125 a-5 p / m i R-141-5 p$ & Prostate cancer & $\mathrm{N} / \mathrm{A}$ & $\mathrm{N} / \mathrm{A}$ & [84] \\
\hline Pan02 CCM & $m i R-155-5 p \& \operatorname{miR}-221-5 p$ & PDAC & $E 2 F 2$ & Promotes PDAC progression & {$[86]$} \\
\hline Cardiac telocyte CCM & $m i R-21-5 p$ & Myocardial infarction & CDIP1 & Promotes angiogenesis & [87] \\
\hline HT-29/SW480 CCM & $m i R-375-3 p$ & Colon cancer & $\mathrm{N} / \mathrm{A}$ & Regulates EMT of colon cancer cells & [88] \\
\hline MSC CCM & $m i R-542-3 p$ & Cerebral infarction & TLR4 & Inhibits inflammation and cerebral infarction & [89] \\
\hline CCa CCM \& serum & $m i R-1468-5 p$ & Cervical cancer & $\begin{array}{c}\text { HMBOX1 \& JAK2/STAT3 } \\
\text { pathway }\end{array}$ & Promotes tumor immune escape & [90] \\
\hline MSC CCM & $m i R-21-5 p$ & Breast cancer & S100A6 & Promotes chemoresistance & [91] \\
\hline Plasma & $m i R-1-3 p$ & Sepsis & SERP1 & Induces endothelial cell dysfunction & [92] \\
\hline Plasma & $m i R-451 a \& m i R-21-5 p$ & $\mathrm{AD}$ & $\mathrm{N} / \mathrm{A}$ & $\mathrm{N} / \mathrm{A}$ & [93] \\
\hline hUCMSC CCM \& serum & $m i R-139-5 p$ & Bladder cancer & PRC1 & Inhibits tumorigenesis & [94] \\
\hline OSCC CCM \& blood & $m i R-340-5 p$ & OSCC & KLF10 & Promotes radioresistance & [95] \\
\hline
\end{tabular}


Table 2. Cont.

\begin{tabular}{|c|c|c|c|c|c|}
\hline Exosome Sources & Potential Biomarkers & Diseases & Target Genes/Pathways & Effects & References \\
\hline Saliva & $m i R-24-3 p$ & OSCC & PER1 & Maintains the proliferation of OSCC cells & [96] \\
\hline Saliva & $m i R-134 \&$ miR-200a & OSCC & $\mathrm{N} / \mathrm{A}$ & $\mathrm{N} / \mathrm{A}$ & [97] \\
\hline Serum & $m i R-1226$ & PDAC & $\mathrm{N} / \mathrm{A}$ & $\mathrm{N} / \mathrm{A}$ & [98] \\
\hline
\end{tabular}

APP: amyloid precursor protein; RGS5: regulator of G protein signaling 5; SOX7: SRY-box transcription factor 7; ABCB1: ATP binding cassette subfamily B member 1; SMAD4: SMAD family member 4; TGF- $\beta$ : transforming growth factor beta 1; B4GALT3: beta-1;4-galactosyltransferase 3; PTEN: phosphatase and tensin homolog; NOTCH1: Notch Receptor 1; E2F2: E2F transcription factor 2; CDIP1: cell death inducing P53 target 1; TLR4: toll-like receptor 4; HMBOX1: homeobox containing 1; JAK2: janus kinase 2; STAT3L: signal transducer and activator of transcription; 3S100A6: S100 calcium binding protein A6; CCM: cell culture media; SERP1: stress associated endoplasmic reticulum protein 1; EBV: epstein-barr virus;

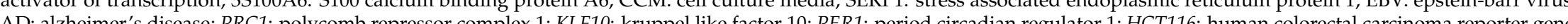
AD: a adenocarcinoma; EMT: epithelial-mesenchymal transition; MSC: mesenchymal stem cell; CCa: cholangiocarcinoma; OSCC: esophageal squamous cell carcinoma.

Table 3. Summary of exosomal lncRNAs as potential disease biomarkers.

\begin{tabular}{|c|c|c|c|c|c|}
\hline Exosome Sources & Potential Biomarkers & Diseases & Effects & Mechanistic Approaches & References \\
\hline Plasma & Linc-POU3F3 & PD & $\mathrm{N} / \mathrm{A}$ & $\mathrm{N} / \mathrm{A}$ & [110] \\
\hline Plasma & $\operatorname{lnc}-M K R N 2-42: 1$ & $\mathrm{PD}$ & $\begin{array}{l}\text { Affects the occurrence and } \\
\text { development of PD }\end{array}$ & $\mathrm{N} / \mathrm{A}$ & [111] \\
\hline Various PC CCM \& serum & $\ln R N A-U C A 1$ & PC & Promotes angiogenesis & miR-96-5p/AMOTL2 axis & [112] \\
\hline Plasma & $B A C E 1-A S$ & $\mathrm{AD}$ & $\mathrm{N} / \mathrm{A}$ & $\mathrm{N} / \mathrm{A}$ & [113] \\
\hline Serum & $H O X D-A S 1$ & Prostate cancer & Promotes metastasis & $m i R-361-5 p / F O X M 1$ axis & [114] \\
\hline Serum & $\operatorname{lncUFC1}$ & NSCLC & $\begin{array}{l}\text { Promotes proliferation, migration, } \\
\text { and invasion }\end{array}$ & $\begin{array}{c}\text { Inhibits PTEN expression via } \\
\text { EZH2-mediated epigenetic silencing }\end{array}$ & [116] \\
\hline Urine & $\ln C B C Y R N 1$ & Bladder cancer & Promotes lymphatic metastasis & $\begin{array}{c}\text { Activates WNT5A/VEGF-C/VEGFR3 } \\
\text { feedforward loop }\end{array}$ & [117] \\
\hline Urine & $\operatorname{lncLNMAT2}$ & Bladder cancer & Promotes lymphatic metastasis & $\mathrm{N} / \mathrm{A}$ & [118] \\
\hline Primary MSCs CCM & LINC01559 & GC & Promotes progression & Multiple approaches & [119] \\
\hline GC CCM \& serum & $\operatorname{lncRNA-GC1}$ & GC & $\mathrm{N} / \mathrm{A}$ & $\mathrm{N} / \mathrm{A}$ & [120] \\
\hline
\end{tabular}


Table 3. Cont.

\begin{tabular}{|c|c|c|c|c|c|}
\hline Exosome Sources & Potential Biomarkers & Diseases & Effects & Mechanistic Approaches & References \\
\hline Urine & TERC & BLCA & $\mathrm{N} / \mathrm{A}$ & $\mathrm{N} / \mathrm{A}$ & [122] \\
\hline M1/M2 macrophage CCM & $\ln C A F A P 1-A S 1$ & Esophageal cancer & Promotes migration and metastasis & $\mathrm{miR}-26 \mathrm{a} / A T F 2$ axis & [123] \\
\hline MSCs CCM & MALAT1 & DICS & $\begin{array}{l}\text { Promotes mitochondrial metabolism } \\
\text { and rejuvenation }\end{array}$ & miR-92a-3p/ATG4a axis & [124] \\
\hline \multirow[t]{2}{*}{ Serum } & H19 & Breast cancer & Reduce DOX resistance & $\mathrm{N} / \mathrm{A}$ & [125] \\
\hline & $\begin{array}{l}\text { PD: Parkinson's disease; CCM } \\
\text { like 2; FOXM1: forkhead box } 1 \\
\text { C: vascular endothelial growth } \\
\text { ATF2: activating transcription } \\
\text { senescence; ATG4a: autophagy }\end{array}$ & $\begin{array}{l}\text { ulture media; PC: panc } \\
\text { IAD5: SMAD family m } \\
\text { C; VEGFR3: vascular er } \\
\text { 2; TERC: telomerase RN } \\
\text { d 4A cysteine peptidase }\end{array}$ & $\begin{array}{l}\text { tic cancer; AD: alzheimer's disease; NSCL } \\
\text { ber 5; EZH2: enhancer of zeste } 2 \text { polycoml } \\
\text { thelial growth factor receptor 3; SNAI1: sna } \\
\text { component; MALAT1: metastasis associate } \\
\text { OX: doxorubicin. }\end{array}$ & $\begin{array}{l}\text { ll-cell lung cancer; GC: gastric } \\
\text { complex } 2 \text { subunit; WNT5A: } \\
\text { nscriptional repressor 1; BLCA } \\
\text { nocarcinoma transcript } 1 \text {; DIC }\end{array}$ & $\begin{array}{l}\text { TL2: angiomo } \\
\text { ember 5A; VEC } \\
\text { thelial car-cinon } \\
\text { n-induced card }\end{array}$ \\
\hline
\end{tabular}




\subsection{Exosomal circRNAs}

Circular RNAs (circRNAs) are a subset of noncoding RNAs that lack $5^{\prime}$ caps and $3^{\prime}$ poly(A) tails and instead have a closed-loop structure [126]. As a class of endogenous RNAs, circRNAs are involved in various biological processes, including alternative splicing, transcription regulation, miRNA sponging, protein scaffolding, interacting with RNA-binding protein (RBP), and pseudogene creation [127-131]. Due to their multiple functions, circRNAs were closely linked to many diseases, such as cancers, neurodegeneration, diabetes, cerebrovascular diseases, and cardiovascular diseases. Thus, the expression of circRNAs could reflect the presence of these diseases [132-135]. Additionally, the closed-loop structure provides circRNAs with resistance to exoribonucleases and a long half-life [136-138]. These characteristics make exosomal circRNAs ideal biomarkers for disease diagnosis.

Exosomal circRNAs were studied as biomarkers for cancer diagnosis. RNA-seq analysis demonstrated that exosomal circRNAs enter circulation and are enriched at least two-fold in exosomes when compared to their levels in donor cells [139]. A study of exosomal circRNAs in colorectal cancer patients and healthy individuals revealed $67 \mathrm{ab}-$ sent circRNAs and 257 new circRNAs in patient serum exosomes, indicating the potential of exosomal circRNAs to act as biomarkers for the diagnosis of colorectal cancers [139]. Another study using microarray sequencing found a significant decrease in plasma exosomal circ-0051443 in patients with hepatocellular carcinoma (HCC), and it was shown that circ-00551443 releaseed BCL2 antagonist/killer 1 (BAK1), which initiated cell apoptosis to prevent HCC via sponging miR-331-3p [140]. As a result, circ-0051443 was considered a tumor suppressor and a novel potential biomarker for HCC diagnosis [140]. As another example, plasma exosomal circ-133 can be used as a biomarker to monitor colorectal tumor progression, as exosomal circ-133 expression induced by hypoxia was able to sponge miR$133 a$ to activate the GEF-H1/RhoA axis in normoxic colorectal cancer cells, leading to the migration of colorectal cancer cells [141].

Exosomal circRNAs can also act as diagnostic biomarkers for nervous system diseases, ischemic diseases, and cardiovascular diseases. In cerebrospinal fluid, 26 exosomal circRNAs were shown to have significantly different expression levels in patients with immune-mediated demyelinating disease (IMDD) when compared to that of healthy controls, while the upregulations of $h s a_{-}$circ_0087862 and $h s a_{-}$circ_0012077 were recommended as potential diagnostic biomarkers for IMDD [138]. After ischemia, vascular smooth muscle cells secrete exosomal circRNA cZFP609, which is delivered into endothelial cells, resulting in reduced vascular endothelial growth factor A (VEGFA) expression and disrupted endothelial angiogenic function via the interaction with and sequestration of hypoxiainducible factor 1 subunit alpha (HIF1 $\alpha$ ) [142]. In this case, cZFP609 may act as a suitable biomarker to assess the clinical outcome and prognosis of ischemic diseases [142].

As a more recently discovered type of exosomal ncRNA, the study of exosomal circRNAs is in an early phase. Although research on exosomal circRNAs is mainly focused on cancer, it was reported that circRNAs are involved in nearly all aspects of biological activities. More exosomal circRNAs will likely be used in the future as biomarkers for the diagnosis of diseases or physiological/pathological processes.

Some examples of exosomal circRNAs with the potential to be used as disease biomarkers are summarized in Table 4. 
Table 4. Summary of exosomal circRNAs as potential disease biomarkers.

\begin{tabular}{|c|c|c|c|c|c|}
\hline Exosome Sources & $\begin{array}{c}\text { Potential } \\
\text { Biomarkers }\end{array}$ & Diseases & Effects & $\begin{array}{l}\text { Mechanistic } \\
\text { Approaches }\end{array}$ & References \\
\hline Serum & circ-G042080 & $\begin{array}{l}\text { Myeloma-related } \\
\text { myocardial damage }\end{array}$ & $\begin{array}{l}\text { Promotes } \\
\text { autophagy }\end{array}$ & $m i R-4268 / T L R 4$ axis & [143] \\
\hline Serum & circGlis3 & Type 2 diabetes & $\begin{array}{l}\text { Regulates islet } \\
\text { EC function }\end{array}$ & $\begin{array}{c}\text { Regulates GMEB1 } \\
\text { degradation \& HSP27 } \\
\text { phosphorylation }\end{array}$ & [144] \\
\hline Plasma & circ-RanGAP1 & Gastric cancer & $\begin{array}{c}\text { Promotes } \\
\text { metastasis and } \\
\text { development }\end{array}$ & $m i R-877-3 p$ & [145] \\
\hline HCC CCM & circRNA-100338 & $\mathrm{HCC}$ & $\begin{array}{c}\text { Promotes } \\
\text { angiogenesis and } \\
\text { invasion }\end{array}$ & $\mathrm{N} / \mathrm{A}$ & [146] \\
\hline Plasma & circRNA_0056616 & $\begin{array}{l}\text { Lymph node } \\
\text { metastasis in lung } \\
\text { adenocarcinoma }\end{array}$ & $\mathrm{N} / \mathrm{A}$ & $\mathrm{N} / \mathrm{A}$ & [147] \\
\hline Serum & circ_0006156 & Thyroid cancer & $\begin{array}{l}\text { Promotes } \\
\text { tumorigenesis }\end{array}$ & miR-1178/TLR4 axis & [148] \\
\hline Serum & $\begin{array}{c}\text { circ_0075828, } \\
\text { circ_0003828 \& } \\
\text { circ_0002976 }\end{array}$ & HGA & $\mathrm{N} / \mathrm{A}$ & $\mathrm{N} / \mathrm{A}$ & [149] \\
\hline Serum & $\begin{array}{l}\text { circRNA_104484 \& } \\
\text { circRNA_104670 }\end{array}$ & Sepsis & $\mathrm{N} / \mathrm{A}$ & $\mathrm{N} / \mathrm{A}$ & [150] \\
\hline Serum & circ-ATP10A & Multiple myeloma & $\begin{array}{l}\text { Promotes } \\
\text { angiogenesis }\end{array}$ & Multiple axises & {$[151]$} \\
\hline $\begin{array}{c}\text { K562 \& K562/G01 } \\
\text { CCM }\end{array}$ & circ_0058493 & CML & Drug resistance & $m i R-548 b-3 p$ & [152] \\
\hline GBM CCM & circNEIL3 & Glioma & $\begin{array}{l}\text { Promotes } \\
\text { progression }\end{array}$ & Stabilizing IGF2BP3 & {$[153]$} \\
\hline
\end{tabular}

CCM: cell culture media; islet EC: islet endothelial cells; HCC: hepatocellular carcinoma; HGA: high-grade astrocytoma; PC: pancreatic cancer; AD: Alzheimer's disease; GC: gastric cancer; BMSCs: bone marrow-derived mesenchymal stromal cells; CML: chronic myeloid leukemia; TLR4: toll like receptor 4; GMEB1: glucocorticoid modulatory element-binding protein 1; HSP27: heat shock protein 27; GBM: glioblastoma multiforme; NEIL3: nei like DNA glycosylase 3; IGF2BP3: insulin-like growth factor 2 mRNA binding protein 3.

\section{Exosome Isolation Techniques}

Critical steps in the functional investigation of exosomes include their enrichment and isolation, which are necessary due to the small size and low density of exosomes as well as the heterogeneity of the bodily fluids in which they are found. To date, six main strategies exist to isolate exosomes from a diverse range of cellular detritus and interfering components, including ultra-speed centrifugation (differential ultracentrifugation and density-gradient ultracentrifugation), immunoaffinity capture, ultrafiltration, size-exclusion chromatography, polymer precipitation, and microfluidics-based techniques [154].

\subsection{Ultra-Speed Centrifugation}

\subsubsection{Differential Ultracentrifugation}

Differential ultracentrifugation is the most common method used to isolate exosomes. The principle of differential centrifugation is that various extracellular components with different densities, sizes, and shapes have different sedimentation rates under centrifugal force. Samples are typically centrifuged at a low speed (e.g., $300 \times g$ ) to eliminate dead cells and debris $[155,156]$. Then, the supernatant is centrifuged at $2000 \times g, 10,000 \times g$, and $100,000 \times g$ to pellet cell debris, apoptotic bodies, and protein aggregates, respectively [154]. Differential ultracentrifugation can isolate a large amount of material at a low cost. Due to this advantage, centrifugation was widely used to isolate exosomes from various biofluids, including cell culture medium, plasma, serum, saliva, and urine [157-159]. However, differential ultracentrifugation requires expensive equipment and a large amount 
of time. Additionally, this method may result in the coprecipitation of exosomes with other particles [160].

\subsubsection{Density-Gradient Ultracentrifugation}

Density-gradient centrifugation separates contents based on their buoyant density in different solutions, such as sucrose and iodixanol [161,162]. A commonly used protocol for density-gradient centrifugation begins with loading $4 \mathrm{~mL}$ of tris $/$ sucrose $/ \mathrm{D}_{2} \mathrm{O}$ solution into the bottom of an SW 28 tube, carefully adding $25 \mathrm{~mL}$ of PBS containing partially isolated exosomes to the top of the sucrose cushion, and then centrifuging for $75 \mathrm{~min}$ at $100,000 \times \mathrm{g}$ at $4{ }^{\circ} \mathrm{C}$ [163]. Thereafter, approximately $3.5 \mathrm{~mL}$ of the Tris/sucrose $/ \mathrm{D}_{2} \mathrm{O}$ cushion is removed from the centrifuge tube and transferred to a fresh centrifuge tube [163]. Then, the mixture is diluted with $60 \mathrm{~mL}$ of PBS and centrifuged for $70 \mathrm{~min}$ at $100,000 \times g$ at $4{ }^{\circ} \mathrm{C}$ [163]. The pellet obtained as a result of this procedure includes the separated exosomes, which should be resuspended in 50-100 mL of PBS [163].

The advantages of this method are the high purity of the resulting products and the ability to separate subpopulations of exosomes. However, density-gradient centrifugation requires expensive ultracentrifugation equipment, which also causes sample loss during isolation. Additionally, density-gradient centrifugation could take as long as two days to isolate different products, which is not time-efficient in comparison to that of other isolation methods $[164,165]$.

\subsection{Immunoaffinity Capture}

Immunoaffinity capture is based on the binding specificity between proteins and their corresponding antibodies. Typically, exosome marker proteins, especially transmembrane proteins, including CD9, CD8, CD63, and Rab5, are used to isolate exosomes $[166,167]$. In one protocol, the exosome pellet is passed through a column containing beads coated with antibodies against CD63, CD9, and CD8 [168]. Then, the antibody beads are washed to separate different exosomal populations. This approach is mostly employed for the further separation of exosomes after they were isolated using a centrifugation process. This approach allows the separation of distinct exosomal populations based on the presence or absence of certain protein markers. On the other hand, this method may lead to the loss of exosomes that lack specific protein markers. Additionally, the number of antibody-coated beads required for exosome separation by immunoprecipitation is proportional to the sample volume employed, which may be expensive.

\subsection{Ultrafiltration}

Ultrafiltration is a technique that employs porous membranes to capture molecules or particles of a given size, where smaller molecules and particles are allowed to pass through a membranous filter, while larger molecules and particles are trapped [169]. In one approach for exosome isolation, larger particles were initially removed by employing filters with pore widths of 0.8 and 0.45 microns, resulting in a filtrate with a high concentration of exosomes. Thereafter, smaller vesicles were removed from the filtrate by passing it through membranes with holes that were smaller than the desired exosomes $(0.22$ and $0.1 \mu \mathrm{m})$, and the eluate was discarded as waste. The size range of the exosomes acquired from the various pore filtration steps was characterized by the maximum and minimum sizes of the exosomes [170]. This approach can be employed as a supplement to ultracentrifugation to separate large microvesicles and exosomes; however, it can also be utilized as a standalone method.

Exosome isolation may also be accomplished using cross-flow filtration (also known as tangential-flow filtration [171]), which is a technique based on consecutive filtrations and the use of nano-ultrafiltration. This process begins with a dead-end filtration of the cells and their detritus, followed by the filtration of large vesicles with a diameter of $1000 \mathrm{~nm}$. Tangential flow-based filtering is used to eliminate impurities (mainly proteins) with a diameter smaller than the size cutoff, which are then disposed of in a trash chamber. The filtrate, which contains exosomes, is then passed through the exclusion filter many times, 
resulting in a concentrated input solution. Finally, exosomes are further separated using a track-etched membrane with a diameter ranging from 50 to $250 \mathrm{~nm}$ and a defined and uniform pore size track [170].

Ultrafiltration can isolate samples with high efficiency beyond the volume limitation, which makes this method a useful substitute for ultracentrifugation [172]. Compared to that of ultracentrifugation, ultrafiltration requires significantly less time. However, there is a risk of filter clogging occurring during analysis, which reduces the lifetime of the membranes [173]. Additionally, the shear forces involved in the process could disrupt the integrity of exosomal membranes, leading to exosome lysis and particle deformation [174].

\subsection{Size-Exclusion Chromatography}

Size-exclusion chromatography is used to separate exosomes from other extracellular vesicles according to their size, and it is conducted using the same method employed for protein separation [175]. The column used for size-exclusion chromatography is filled with a porous stationary phase through which tiny particles may pass. This penetration is responsible for the slower flow of the smaller particles down the tube, which causes them to elute later in the gradient and after the larger particles [176,177].

Size-exclusion chromatography can be used to purify exosomes while preserving the vesicle structure, integrity, and biological activity. The isolated exosomes also maintain their proper vesicle characteristics due to gravity manipulation, which avoids the damage caused by shear forces. Although this increased quality comes at the expense of the overall yield of exosomes, size-exclusion chromatography procedures can be scaled up to obtain higher yields. A substantial amount of initial biofluid is necessary to compensate for the lower yield if the recovery rate is only moderate [178]. In addition, size-exclusion chromatography could reduce the production of exosomal mRNA and exosomal protein.

\subsection{Polymer Precipitation}

The presence of highly hydrophilic polymers can create a hydrophobic micro-environment through their interaction with the water molecules surrounding exosomes, leading to exosome precipitation [179]. Polyethylene glycol (PEG) with weights ranging from 6000 to $20,000 \mathrm{Da}$ is widely used for the polymer-based exosome precipitation method. In this method, large contaminant particles, including debris and apoptotic bodies, are first removed during a pretreatment step [180]. The samples are then incubated with a PEG solution at $4{ }^{\circ} \mathrm{C}$ overnight to induce exosome precipitation [180]. Low-speed centrifugation $(1500 \times g)$ is then used to collect the precipitated exosomes [180].

Lectin precipitation is an alternative to PEG precipitation. Lectins bind the carbohydrate moieties of other particles with extreme specificity. Lectins are thus able to attach to carbohydrates on the surface of exosomes and affect their solubility, making the exosomes insoluble and causing them to precipitate out of solution [181].

Precipitation using highly hydrophilic polymers is rapid, simple, low-cost, and does not require complicated equipment. However, the final exosome pellet becomes contaminated, which prevents further omics-based analysis for exosomes. Although this makes the precipitation method ineffective in clinical research settings, it is effective in other situations.

\subsection{Microfluidics-Based Techniques}

Tremendous recent developments in microfabrication technology enabled the creation of lab-on-a-chip-type microfluidic devices for effective exosome separation [182-184]. These small microfluidic machines enable exosome separation from fingertip amounts of bodily fluids and exosome characterization for in situ diagnoses. Microfluidic technology is revolutionizing exosome-based diagnostics by combining what is usually a two-step approach involving exosome separation and characterization into one step [184]. The immuno-microfluidic approach is a widely used microfluidics-based method that is comparable to the immunoaffinity capture isolation method. Exosomes are isolated via the specific binding between protein markers and the microfluidic devices. For example, the 
ExoChip is a popular microfluidic device that was employed in conjunction with CD63 antibodies [185].

The benefits of microfluidic technology include efficient and rapid processing and the high purity of resulting exosomes. More importantly, microfluidic techniques can isolate exosomes based on their physical and biochemical properties simultaneously. Apart from the requirement for specialized equipment, this method suffers from many of the same disadvantages as the aforementioned immunoaffinity capture method described previously. Although microfluidics-based techniques were not accepted as a standardized exosome isolation method, they have great potential for use in the future.

Here, the advantages and disadvantages of above exosome isolation techniques are summarized in Table 5.

Table 5. Summary of advantages and disadvantages of exosome isolation techniques.

\begin{tabular}{|c|c|c|}
\hline Isolation Techniques & Advantages & Disadvantages \\
\hline $\begin{array}{ll}\text { - } & \text { Differential } \\
& \text { ultracentrifugation }\end{array}$ & $\begin{array}{l}\text { - } \quad \text { Low cost } \\
\text { - } \quad \text { Suitable to isolate a large amount } \\
\text { of material } \\
\text { - } \quad \text { Low risk of reagent pollution; }\end{array}$ & $\begin{array}{l}\text { - } \\
\text { - } \\
\text { - } \\
\text { - } \\
\text { - }\end{array}$ \\
\hline $\begin{array}{l}\text { Density-gradient } \\
\text { ultracentrifugation }\end{array}$ & $\begin{array}{l}\text { - High purity of resulting products } \\
\text { - } \quad \text { Separating subpopulations of exosomes }\end{array}$ & $\begin{array}{ll}\text { - } & \text { Heavy workload, low recovery. } \\
\text { - } & \text { Complicated steps } \\
\text { - } & \text { Time-consuming } \\
\text { - } & \text { Low recovery }\end{array}$ \\
\hline $\begin{array}{l}\text { Immunoaffinity } \\
\text { capture }\end{array}$ & $\begin{array}{l}\text { - } \quad \text { High specificity } \\
\text { - } \quad \text { Simple operation } \\
\text { - } \quad \text { No chemical pollution }\end{array}$ & $\begin{array}{ll}\text { - } & \text { Low extraction efficiency } \\
\text { - } & \text { High cost of antibodies } \\
\text { - } & \text { Potential pollution of } \mathrm{pH} \text { and salt concentration } \\
\text { - } & \text { Isolation for antibody-bound exosomes only } \\
\text { - } & \text { Low processing volume }\end{array}$ \\
\hline - Ultrafiltration & $\begin{array}{l}\text { - } \quad \text { Fast } \\
\text { - } \quad \text { Cheap equipment cost }\end{array}$ & $\begin{array}{l}\text { - } \quad \text { Moderate exosome yield and purity } \\
\text { - } \\
\text { - } \\
\text { Potential shear stress induced deterioration } \\
\text { trapping and clogging }\end{array}$ \\
\hline $\begin{array}{l}\text { - Size-exclusion } \\
\text { chromatography }\end{array}$ & $\begin{array}{l}\text { - High purity of resulting products } \\
\text { - Fast }\end{array}$ & $\begin{array}{ll}\text { - } & \text { Moderate exosome yield } \\
\text { - } & \text { High cost } \\
\text { - } & \text { Time-consuming } \\
\text { - } & \text { Require high-quality chromatographic column } \\
\text { - } & \text { Require extra exosome enrichment step }\end{array}$ \\
\hline $\begin{array}{ll}\text { - } & \text { Polymer } \\
\text { precipitation }\end{array}$ & $\begin{array}{ll}\text { - } & \text { Easy to use } \\
\text { - } & \text { No special equipment requirement } \\
\text { - } & \text { Multiple sample processing } \\
\text { - } & \text { Low cost } \\
\text { - } & \text { Low risk of exosome damage }\end{array}$ & $\begin{array}{l}\text { - } \quad \text { Low exosome purity } \\
\text { - } \quad \text { Limiting further omics-based analysis } \\
\text { - } \quad \text { Require extra complicated clean-up steps }\end{array}$ \\
\hline $\begin{array}{l}\text { - Microfluidics-based } \\
\text { techniques }\end{array}$ & $\begin{array}{ll}\text { - } & \text { Sample volume requirement } \\
\text { - } & \text { Fast } \\
\text { - } & \text { Relative low cost } \\
\text { - } & \text { High detection sensitivity } \\
\text { - } & \text { Multifunctional operations integration }\end{array}$ & - $\quad$ Low sample capacity \\
\hline
\end{tabular}




\section{Conclusions}

Exosomal mRNAs, miRNAs, lncRNAs, and circRNAs are important mediators of intercellular communication, and they will absolutely provide essential clues and huge opportunities in disease diagnosis in the near future. The investigation of exosomal biomarkers highlighted their great value in diagnosis and prognosis since they avoid the limitations of conventional solid biopsy, especially by reducing the trauma associated with surgery.

However, the exploration of exosomal biomarkers is still in the early phase, and a ubiquitous clinical application is greatly limited.

Although the convenience of exosomal biomarkers is undisputed, challenges still remain with biomarker selection, and no biomarker can achieve $100 \%$ accuracy. Future efforts should focus on identifying the most significant changed biomarkers to improve the accuracy of disease diagnosis. Therefore, detailed mechanisms of exosomal RNAs require further investigation.

To analyze clinical samples on a large scale in the feature, it is necessary to extract exosomes more rapidly, accurately, and completely, thereby implementing the use of exosomes as new biomarkers into clinical practice. To date, there is no uniform standard for the isolation, purification, or quality assessment of exosomes, which also restricts the progress of research on exosomal diagnostic technology. Therefore, further study is required to develop new methods to enhance the exosome isolation and purity, which would greatly benefit the research on the clinical applications of exosomes as disease biomarkers. Despite the insights highlighted in this review, a more comprehensive view of exosomal biomarkers requires further investigation.

Challenges still remain in the field of exosomal RNAs as biomarkers. However, exosomal RNAs will definitely provide exciting new insights and outline promising fields for the development of novel therapeutic strategies.

Author Contributions: J.W. and H.C. designed the work and wrote the manuscript; B.-L.Y., Y.-Z.H. and X.-Y.L. organized the materials; W.-J.L. and H.C. revised the manuscript. All authors have read and agreed to the published version of the manuscript.

Funding: This study was supported by the National Natural Science Foundation of China (No. 31972558) and the Agricultural Improved Seed Project of Shandong Province (Grant No. 2020LZGC014).

Institutional Review Board Statement: Not applicable.

Informed Consent Statement: Not applicable.

Data Availability Statement: Not applicable.

Acknowledgments: We appreciate Mengmeng Liu for the valuable advice on the manuscript.

Conflicts of Interest: All authors declare that there is no conflict of interest.

\section{References}

1. Kalluri, R.; LeBleu, V.S. The biology, function, and biomedical applications of exosomes. Science 2020, 367, eaau6977. [CrossRef] [PubMed]

2. Valadi, H.; Ekström, K.; Bossios, A.; Sjöstrand, M.; Lee, J.J.; Lötvall, J.O. Exosome-mediated transfer of mRNAs and microRNAs is a novel mechanism of genetic exchange between cells. Nat. Cell Biol. 2007, 9, 654-659. [CrossRef] [PubMed]

3. Caby, M.-P.; Lankar, D.; Vincendeau-Scherrer, C.; Raposo, G.; Bonnerot, C. Exosomal-like vesicles are present in human blood plasma. Int. Immunol. 2005, 17, 879-887. [CrossRef] [PubMed]

4. Pisitkun, T.; Shen, R.-F.; Knepper, M.A. Identification and proteomic profiling of exosomes in human urine. Proc. Natl. Acad. Sci. USA 2004, 101, 13368. [CrossRef] [PubMed]

5. Zlotogorski-Hurvitz, A.; Dayan, D.; Chaushu, G.; Korvala, J.; Salo, T.; Sormunen, R.; Vered, M. Human saliva-derived exosomes: Comparing methods of isolation. J. Histochem. Cytochem. 2015, 63, 181-189. [CrossRef]

6. Adriano, B.; Cotto, N.M.; Chauhan, N.; Jaggi, M.; Chauhan, S.C.; Yallapu, M.M. Milk exosomes: Nature's abundant nanoplatform for theranostic applications. Bioact. Mater. 2021, 6, 2479-2490. [CrossRef] 
7. Dini, L.; Tacconi, S.; Carata, E.; Tata, A.M.; Vergallo, C.; Panzarini, E. Microvesicles and exosomes in metabolic diseases and inflammation. Cytokine Growth Factor Rev. 2020, 51, 27-39. [CrossRef]

8. Gehrmann, U.; Näslund, T.I.; Hiltbrunner, S.; Larssen, P.; Gabrielsson, S. Harnessing the exosome-induced immune response for cancer immunotherapy. Semin. Cancer Biol. 2014, 28, 58-67. [CrossRef]

9. D'Anca, M.; Fenoglio, C.; Serpente, M.; Arosio, B.; Cesari, M.; Scarpini, E.A.; Galimberti, D. Exosome Determinants of Physiological Aging and Age-Related Neurodegenerative Diseases. Front. Aging Neurosci. 2019, 11, 232. [CrossRef]

10. Yang, E.; Wang, X.; Gong, Z.; Yu, M.; Wu, H.; Zhang, D. Exosome-mediated metabolic reprogramming: The emerging role in tumor microenvironment remodeling and its influence on cancer progression. Signal Transduct. Target. Ther. 2020, 5, 242. [CrossRef]

11. Hosseini, K.; Ranjbar, M.; Pirpour Tazehkand, A.; Asgharian, P.; Montazersaheb, S.; Tarhriz, V.; Ghasemnejad, T. Evaluation of exosomal non-coding RNAs in cancer using high-throughput sequencing. J. Transl. Med. 2022, 20, 30. [CrossRef] [PubMed]

12. Yang, K.; Zhou, Q.; Qiao, B.; Shao, B.; Hu, S.; Wang, G.; Yuan, W.; Sun, Z. Exosome-derived noncoding RNAs: Function, mechanism, and application in tumor angiogenesis. Mol. Ther. Nucleic Acids 2022, 27, 983-997. [CrossRef]

13. Hessvik, N.P.; Llorente, A. Current knowledge on exosome biogenesis and release. Cell. Mol. Life Sci. 2018, 75, 193-208. [CrossRef] [PubMed]

14. Colombo, M.; Moita, C.; Van Niel, G.; Kowal, J.; Vigneron, J.; Benaroch, P.; Manel, N.; Moita, L.F.; Théry, C.; Raposo, G. Analysis of ESCRT functions in exosome biogenesis, composition and secretion highlights the heterogeneity of extracellular vesicles. J. Cell Sci. 2013, 126, 5553-5565. [CrossRef]

15. Baietti, M.F.; Zhang, Z.; Mortier, E.; Melchior, A.; Degeest, G.; Geeraerts, A.; Ivarsson, Y.; Depoortere, F.; Coomans, C.; Vermeiren, E.; et al. Syndecan-syntenin-ALIX regulates the biogenesis of exosomes. Nat. Cell Biol. 2012, 14, 677-685. [CrossRef] [PubMed]

16. Larios, J.; Mercier, V.; Roux, A.; Gruenberg, J. ALIX- and ESCRT-III-dependent sorting of tetraspanins to exosomes. J. Cell Biol. 2020, 219, e201904113. [CrossRef]

17. Kenific, C.M.; Zhang, H.; Lyden, D. An exosome pathway without an ESCRT. Cell Res. 2021, 31, 105-106. [CrossRef]

18. Lata, S.; Schoehn, G.; Jain, A.; Pires, R.; Piehler, J.; Gőttlinger Heinrich, G.; Weissenhorn, W. Helical Structures of ESCRT-III Are Disassembled by VPS4. Science 2008, 321, 1354-1357. [CrossRef] [PubMed]

19. Hariharan, H.; Kesavan, Y.; Raja, N.S. Impact of native and external factors on exosome release: Understanding reactive exosome secretion and its biogenesis. Mol. Biol. Rep. 2021, 48, 7559-7573. [CrossRef]

20. Trajkovic, K.; Hsu, C.; Chiantia, S.; Rajendran, L.; Wenzel, D.; Wieland, F.; Schwille, P.; Brügger, B.; Simons, M. Ceramide Triggers Budding of Exosome Vesicles into Multivesicular Endosomes. Science 2008, 319, 1244-1247. [CrossRef]

21. Grassart, A.; Cheng, A.T.; Hong, S.H.; Zhang, F.; Zenzer, N.; Feng, Y.; Briner, D.M.; Davis, G.D.; Malkov, D.; Drubin, D.G. Actin and dynamin2 dynamics and interplay during clathrin-mediated endocytosis. J. Cell Biol. 2014, 205, 721-735. [CrossRef] [PubMed]

22. Wubbolts, R.; Leckie, R.S.; Veenhuizen, P.T.M.; Schwarzmann, G.; Möbius, W.; Hoernschemeyer, J.; Slot, J.-W.; Geuze, H.J.; Stoorvogel, W. Proteomic and Biochemical Analyses of Human B Cell-derived Exosomes: Potential implications for their function and multivesicular body formation. J. Biol. Chem. 2003, 278, 10963-10972. [CrossRef]

23. Janas, T.; Janas, M.M.; Sapoń, K.; Janas, T. Mechanisms of RNA loading into exosomes. FEBS Lett. 2015, 589, 1391-1398. [CrossRef]

24. Svensson, K.J.; Christianson, H.C.; Wittrup, A.; Bourseau-Guilmain, E.; Lindqvist, E.; Svensson, L.M.; Mörgelin, M.; Belting, M. Exosome Uptake Depends on ERK1/2-Heat Shock Protein 27 Signaling and Lipid Raft-mediated Endocytosis Negatively Regulated by Caveolin-1. J. Biol. Chem. 2013, 288, 17713-17724. [CrossRef]

25. Phuyal, S.; Hessvik, N.P.; Skotland, T.; Sandvig, K.; Llorente, A. Regulation of exosome release by glycosphingolipids and flotillins. FEBS J. 2014, 281, 2214-2227. [CrossRef]

26. Elsherbini, A.; Bieberich, E. Chapter Five-Ceramide and Exosomes: A Novel Target in Cancer Biology and Therapy. In Advances in Cancer Research; Chalfant, C.E., Fisher, P.B., Eds.; Academic Press: Cambridge, MA, USA, 2018; Volume 140, pp. 121-154.

27. Kajimoto, T.; Okada, T.; Miya, S.; Zhang, L.; Nakamura, S.-I. Ongoing activation of sphingosine 1-phosphate receptors mediates maturation of exosomal multivesicular endosomes. Nat. Commun. 2013, 4, 2712. [CrossRef] [PubMed]

28. Kummer, D.; Steinbacher, T.; Schwietzer, M.F.; Thölmann, S.; Ebnet, K. Tetraspanins: Integrating cell surface receptors to functional microdomains in homeostasis and disease. Med. Microbiol. Immunol. 2020, 209, 397-405. [CrossRef] [PubMed]

29. Stuffers, S.; Sem Wegner, C.; Stenmark, H.; Brech, A. Multivesicular Endosome Biogenesis in the Absence of ESCRTs. Traffic 2009, 10, 925-937. [CrossRef] [PubMed]

30. Yue, B.; Yang, H.; Wang, J.; Ru, W.; Wu, J.; Huang, Y.; Lan, X.; Lei, C.; Chen, H. Exosome biogenesis, secretion and function of exosomal miRNAs in skeletal muscle myogenesis. Cell Prolif. 2020, 53, e12857. [CrossRef]

31. Mittelbrunn, M.; Vicente Manzanares, M.; Sánchez-Madrid, F. Organizing polarized delivery of exosomes at synapses. Traffic 2015, 16, 327-337. [CrossRef]

32. Saito, N.; Okada, Y.; Noda, Y.; Kinoshita, Y.; Kondo, S.; Hirokawa, N. KIFC2 Is a Novel Neuron-Specific C-Terminal Type Kinesin Superfamily Motor for Dendritic Transport of Multivesicular Body-Like Organelles. Neuron 1997, 18, 425-438. [CrossRef]

33. Zerial, M.; McBride, H. Rab proteins as membrane organizers. Nat. Rev. Mol. Cell Biol. 2001, 2, 107-117. [CrossRef] [PubMed] 
34. Mashouri, L.; Yousefi, H.; Aref, A.R.; Ahadi, A.m.; Molaei, F.; Alahari, S.K. Exosomes: Composition, biogenesis, and mechanisms in cancer metastasis and drug resistance. Mol. Cancer 2019, 18, 75. [CrossRef] [PubMed]

35. Pegtel, D.M.; Gould, S.J. Exosomes. Extracellular vesicles: Exosomes, microvesicles, and friends. Annu. Rev. Biochem. 2019, 88, 487-514. [CrossRef]

36. He, C.; Zheng, S.; Luo, Y.; Wang, B. Exosome Theranostics: Biology and Translational Medicine. Theranostics 2018, 8, 237-255. [CrossRef]

37. Mulcahy, L.A.; Pink, R.C.; Carter, D.R.F. Routes and mechanisms of extracellular vesicle uptake. J. Extracell. Vesicles $2014,3,24641$. [CrossRef] [PubMed]

38. Pironti, G.; Strachan, R.T.; Abraham, D.; Mon-Wei Yu, S.; Chen, M.; Chen, W.; Hanada, K.; Mao, L.; Watson, L.J.; Rockman, H.A. Circulating Exosomes Induced by Cardiac Pressure Overload Contain Functional Angiotensin II Type 1 Receptors. Circulation 2015, 131, 2120-2130. [CrossRef]

39. Li, S.; Li, Y.; Chen, B.; Zhao, J.; Yu, S.; Tang, Y.; Zheng, Q.; Li, Y.; Wang, P.; He, X.; et al. exoRBase: A database of circRNA, lncRNA and mRNA in human blood exosomes. Nucleic Acids Res. 2018, 46, D106-D112. [CrossRef]

40. Miranda, K.C.; Bond, D.T.; McKee, M.; Skog, J.; Păunescu, T.G.; Da Silva, N.; Brown, D.; Russo, L.M. Nucleic acids within urinary exosomes/microvesicles are potential biomarkers for renal disease. Kidney Int. 2010, 78, 191-199. [CrossRef]

41. El Fekih, R.; Hurley, J.; Tadigotla, V.; Alghamdi, A.; Srivastava, A.; Coticchia, C.; Choi, J.; Allos, H.; Yatim, K.; Alhaddad, J.; et al. Discovery and Validation of a Urinary Exosome mRNA Signature for the Diagnosis of Human Kidney Transplant Rejection. J. Am. Soc. Nephrol. 2021, 32, 994. [CrossRef]

42. Skog, J.; Würdinger, T.; Van Rijn, S.; Meijer, D.H.; Gainche, L.; Curry, W.T.; Carter, B.S.; Krichevsky, A.M.; Breakefield, X.O. Glioblastoma microvesicles transport RNA and proteins that promote tumour growth and provide diagnostic biomarkers. Nat. Cell Biol. 2008, 10, 1470-1476. [CrossRef] [PubMed]

43. Phatak, P.; Burger, A.M. Telomerase and its potential for therapeutic intervention. Br. J. Pharmacol. 2007, 152, 1003-1011. [CrossRef] [PubMed]

44. Goldvaser, H.; Gutkin, A.; Beery, E.; Edel, Y.; Nordenberg, J.; Wolach, O.; Rabizadeh, E.; Uziel, O.; Lahav, M. Characterisation of blood-derived exosomal hTERT mRNA secretion in cancer patients: A potential pan-cancer marker. Br. J. Cancer 2017, 117, 353-357. [CrossRef] [PubMed]

45. Xu, H.; Dong, X.; Chen, Y.; Wang, X. Serum exosomal hnRNPH1 mRNA as a novel marker for hepatocellular carcinoma. Clin. Chem. Lab. Med. CCLM 2018, 56, 479-484. [CrossRef] [PubMed]

46. Hamley, I.W. The Amyloid Beta Peptide: A Chemist's Perspective. Role in Alzheimer's and Fibrillization. Chem. Rev. 2012, 112, 5147-5192. [CrossRef]

47. Mitsuhashi, M.; Taub, D.D.; Kapogiannis, D.; Eitan, E.; Zukley, L.; Mattson, M.P.; Ferrucci, L.; Schwartz, J.B.; Goetzl, E.J. Aging

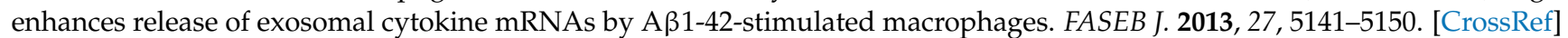

48. Lv, L.-L.; Cao, Y.-H.; Pan, M.-M.; Liu, H.; Tang, R.-N.; Ma, K.-L.; Chen, P.-S.; Liu, B.-C. CD2AP mRNA in urinary exosome as biomarker of kidney disease. Clin. Chim. Acta 2014, 428, 26-31. [CrossRef]

49. Shao, H.; Chung, J.; Lee, K.; Balaj, L.; Min, C.; Carter, B.S.; Hochberg, F.H.; Breakefield, X.O.; Lee, H.; Weissleder, R. Chip-based analysis of exosomal mRNA mediating drug resistance in glioblastoma. Nat. Commun. 2015, 6, 6999. [CrossRef]

50. McKiernan, J.; Donovan, M.J.; O’Neill, V.; Bentink, S.; Noerholm, M.; Belzer, S.; Skog, J.; Kattan, M.W.; Partin, A.; Andriole, G.; et al. A Novel Urine Exosome Gene Expression Assay to Predict High-grade Prostate Cancer at Initial Biopsy. JAMA Oncol. 2016, 2, 882-889. [CrossRef]

51. McKiernan, J.; Donovan, M.J.; Margolis, E.; Partin, A.; Carter, B.; Brown, G.; Torkler, P.; Noerholm, M.; Skog, J.; Shore, N.; et al. A Prospective Adaptive Utility Trial to Validate Performance of a Novel Urine Exosome Gene Expression Assay to Predict High-grade Prostate Cancer in Patients with Prostate-specific Antigen 2-10 ng/mL at Initial Biopsy. Eur. Urol. 2018, 74, 731-738. [CrossRef]

52. Tutrone, R.; Donovan, M.J.; Torkler, P.; Tadigotla, V.; McLain, T.; Noerholm, M.; Skog, J.; McKiernan, J. Clinical utility of the exosome based ExoDx Prostate(IntelliScore) EPI test in men presenting for initial Biopsy with a PSA 2-10 ng/mL. Prostate Cancer Prostatic Dis. 2020, 23, 607-614. [CrossRef] [PubMed]

53. Zeng, A.L.; Yan, W.; Liu, Y.W.; Wang, Z.; Hu, Q.; Nie, E.; Zhou, X.; Li, R.; Wang, X.F.; Jiang, T.; et al. Tumour exosomes from cells harbouring PTPRZ1-MET fusion contribute to a malignant phenotype and temozolomide chemoresistance in glioblastoma. Oncogene 2017, 36, 5369-5381. [CrossRef] [PubMed]

54. Kato, T.; Mizutani, K.; Kawakami, K.; Fujita, Y.; Ehara, H.; Ito, M. CD44v8-10 mRNA contained in serum exosomes as a diagnostic marker for docetaxel resistance in prostate cancer patients. Heliyon 2020, 6, e04138. [CrossRef] [PubMed]

55. Pope, S.M.; Lässer, C. Toxoplasma gondii infection of fibroblasts causes the production of exosome-like vesicles containing a unique array of mRNA and miRNA transcripts compared to serum starvation. J. Extracell. Vesicles 2013, 2, 22484. [CrossRef] [PubMed]

56. Hao, Y.X.; Li, Y.M.; Ye, M.; Guo, Y.Y.; Li, Q.W.; Peng, X.M.; Wang, Q.; Zhang, S.F.; Zhao, H.X.; Zhang, H.; et al. KRAS and BRAF mutations in serum exosomes from patients with colorectal cancer in a Chinese population. Oncol. Lett. 2017, 13, 3608-3616. [CrossRef] 
57. Dong, Z.; Sun, X.; Xu, J.; Han, X.; Xing, Z.; Wang, D.; Ge, J.; Meng, L.; Xu, X. Serum Membrane Type 1-Matrix Metalloproteinase (MT1-MMP) mRNA Protected by Exosomes as a Potential Biomarker for Gastric Cancer. Med. Sci. Monit. 2019, 25, 7770-7783. [CrossRef]

58. Del Re, M.; Biasco, E.; Crucitta, S.; Derosa, L.; Rofi, E.; Orlandini, C.; Miccoli, M.; Galli, L.; Falcone, A.; Jenster, G.W.; et al. The Detection of Androgen Receptor Splice Variant 7 in Plasma-derived Exosomal RNA Strongly Predicts Resistance to Hormonal Therapy in Metastatic Prostate Cancer Patients. Eur. Urol. 2017, 71, 680-687. [CrossRef]

59. Kitagawa, T.; Taniuchi, K.; Tsuboi, M.; Sakaguchi, M.; Kohsaki, T.; Okabayashi, T.; Saibara, T. Circulating pancreatic cancer exosomal RNAs for detection of pancreatic cancer. Mol. Oncol. 2019, 13, 212-227. [CrossRef]

60. Haque, S.; Vaiselbuh, S.R. Exosomal DNMT1 mRNA transcript is elevated in acute lymphoblastic leukemia which might reprograms leukemia progression. Cancer Genet. 2022, 260-261, 57-64. [CrossRef]

61. Wahid, F.; Shehzad, A.; Khan, T.; Kim, Y.Y. MicroRNAs: Synthesis, mechanism, function, and recent clinical trials. Biochim. Biophys. Acta BBA Mol. Cell Res. 2010, 1803, 1231-1243. [CrossRef]

62. Bartel, D.P. MicroRNAs: Genomics, Biogenesis, Mechanism, and Function. Cell 2004, 116, 281-297. [CrossRef]

63. Lu, J.; Getz, G.; Miska, E.A.; Alvarez-Saavedra, E.; Lamb, J.; Peck, D.; Sweet-Cordero, A.; Ebert, B.L.; Mak, R.H.; Ferrando, A.A.; et al. MicroRNA expression profiles classify human cancers. Nature 2005, 435, 834-838. [CrossRef] [PubMed]

64. Liz, J.; Esteller, M. lncRNAs and microRNAs with a role in cancer development. Biochim. Biophys. Acta BBA Gene Regul. Mech. 2016, 1859, 169-176. [CrossRef] [PubMed]

65. Weber, J.A.; Baxter, D.H.; Zhang, S.; Huang, D.Y.; How Huang, K.; Jen Lee, M.; Galas, D.J.; Wang, K. The MicroRNA Spectrum in 12 Body Fluids. Clin. Chem. 2010, 56, 1733-1741. [CrossRef]

66. Zhang, L.; Zhang, S.; Yao, J.; Lowery, F.J.; Zhang, Q.; Huang, W.-C.; Li, P.; Li, M.; Wang, X.; Zhang, C.; et al. Microenvironmentinduced PTEN loss by exosomal microRNA primes brain metastasis outgrowth. Nature 2015, 527, 100-104. [CrossRef]

67. Wang, D.; Wang, X.; Si, M.; Yang, J.; Sun, S.; Wu, H.; Cui, S.; Qu, X.; Yu, X. Exosome-encapsulated miRNAs contribute to CXCL12/CXCR4-induced liver metastasis of colorectal cancer by enhancing M2 polarization of macrophages. Cancer Lett. 2020, 474, 36-52. [CrossRef]

68. Orecchioni, M.; Ghosheh, Y.; Pramod, A.B.; Ley, K. Macrophage Polarization: Different Gene Signatures in M1(LPS+) vs. Classically and M2(LPS-) vs. Alternatively Activated Macrophages. Front. Immunol. 2019, 10, 1084. [CrossRef]

69. Ying, W.; Gao, H.; Dos Reis, F.C.G.; Bandyopadhyay, G.; Ofrecio, J.M.; Luo, Z.; Ji, Y.; Jin, Z.; Ly, C.; Olefsky, J.M. MiR-690, an exosomal-derived miRNA from M2-polarized macrophages, improves insulin sensitivity in obese mice. Cell Metab. 2021, 33, 781-790.e785. [CrossRef]

70. Pfeffer, S.; Zavolan, M.; Grässer Friedrich, A.; Chien, M.; Russo James, J.; Ju, J.; John, B.; Enright Anton, J.; Marks, D.; Sander, C.; et al. Identification of Virus-Encoded MicroRNAs. Science 2004, 304, 734-736. [CrossRef]

71. Pegtel, D.M.; Cosmopoulos, K.; Thorley-Lawson, D.A.; Van Eijndhoven, M.A.J.; Hopmans, E.S.; Lindenberg, J.L.; De Gruijl, T.D.; Würdinger, T.; Middeldorp, J.M. Functional delivery of viral miRNAs via exosomes. Proc. Natl. Acad. Sci. USA 2010, 107, 6328. [CrossRef]

72. Liu, C.-G.; Song, J.; Zhang, Y.-Q.; Wang, P.-C. MicroRNA-193b is a regulator of amyloid precursor protein in the blood and cerebrospinal fluid derived exosomal microRNA-193b is a biomarker of Alzheimer's disease. Mol. Med. Rep. 2014, 10, 2395-2400. [CrossRef]

73. Lucero, R.; Zappulli, V.; Sammarco, A.; Murillo, O.D.; Cheah, P.S.; Srinivasan, S.; Tai, E.; Ting, D.T.; Wei, Z.; Roth, M.E.; et al. Glioma-Derived miRNA-Containing Extracellular Vesicles Induce Angiogenesis by Reprogramming Brain Endothelial Cells. Cell Rep. 2020, 30, 2065-2074.e2064. [CrossRef] [PubMed]

74. Ibrahim, A.G.-E.; Cheng, K.; Marbán, E. Exosomes as Critical Agents of Cardiac Regeneration Triggered by Cell Therapy. Stem Cell Rep. 2014, 2, 606-619. [CrossRef] [PubMed]

75. Samsonov, R.; Burdakov, V.; Shtam, T.; Radzhabova, Z.; Vasilyev, D.; Tsyrlina, E.; Titov, S.; Ivanov, M.; Berstein, L.; Filatov, M.; et al. Plasma exosomal miR-21 and miR-181a differentiates follicular from papillary thyroid cancer. Tumor Biol. 2016, 37, 12011-12021. [CrossRef] [PubMed]

76. Fang, T.; Lv, H.; Lv, G.; Li, T.; Wang, C.; Han, Q.; Yu, L.; Su, B.; Guo, L.; Huang, S.; et al. Tumor-derived exosomal miR-1247-3p induces cancer-associated fibroblast activation to foster lung metastasis of liver cancer. Nat. Commun. 2018, 9, 191. [CrossRef]

77. Zhu, X.; Shen, H.; Yin, X.; Yang, M.; Wei, H.; Chen, Q.; Feng, F.; Liu, Y.; Xu, W.; Li, Y. Macrophages derived exosomes deliver miR-223 to epithelial ovarian cancer cells to elicit a chemoresistant phenotype. J. Exp. Clin. Cancer Res. 2019, 38, 81. [CrossRef] [PubMed]

78. Bica-Pop, C.; Cojocneanu-Petric, R.; Magdo, L.; Raduly, L.; Gulei, D.; Berindan-Neagoe, I. Overview upon miR-21 in lung cancer: Focus on NSCLC. Cell. Mol. Life Sci. 2018, 75, 3539-3551. [CrossRef]

79. Hannafon, B.N.; Trigoso, Y.D.; Calloway, C.L.; Zhao, Y.D.; Lum, D.H.; Welm, A.L.; Zhao, Z.J.; Blick, K.E.; Dooley, W.C.; Ding, W.Q. Plasma exosome microRNAs are indicative of breast cancer. Breast Cancer Res. 2016, 18, 90. [CrossRef] [PubMed]

80. Zhao, L.; Yu, J.; Wang, J.; Li, H.; Che, J.; Cao, B. Isolation and Identification of miRNAs in exosomes derived from serum of colon cancer patients. J. Cancer 2017, 8, 1145-1152. [CrossRef]

81. Santangelo, A.; Imbrucè, P.; Gardenghi, B.; Belli, L.; Agushi, R.; Tamanini, A.; Munari, S.; Bossi, A.M.; Scambi, I.; Benati, D.; et al. A microRNA signature from serum exosomes of patients with glioma as complementary diagnostic biomarker. J. Neuro-Oncol. 2018, 136, 51-62. [CrossRef] 
82. Yuan, X.; Qian, N.; Ling, S.; Li, Y.; Sun, W.; Li, J.; Du, R.; Zhong, G.; Liu, C.; Yu, G.; et al. Breast cancer exosomes contribute to pre-metastatic niche formation and promote bone metastasis of tumor cells. Theranostics 2021, 11, 1429-1445. [CrossRef] [PubMed]

83. Zhang, D.; Cai, G.; Liu, K.; Zhuang, Z.; Jia, K.; Pei, S.; Wang, X.; Wang, H.; Xu, S.; Cui, C.; et al. Microglia exosomal miRNA-137 attenuates ischemic brain injury through targeting Notch1. Aging 2021, 13, 4079-4095. [CrossRef] [PubMed]

84. Zabegina, L.; Nazarova, I.; Nikiforova, N.; Slyusarenko, M.; Sidina, E.; Knyazeva, M.; Tsyrlina, E.; Novikov, S.; Reva, S.; Malek, A. A New Approach for Prostate Cancer Diagnosis by miRNA Profiling of Prostate-Derived Plasma Small Extracellular Vesicles. Cells 2021, 10, 2372. [CrossRef]

85. Chen, L.; Cao, P.; Huang, C.; Wu, Q.; Chen, S.; Chen, F. Serum exosomal miR-7977 as a novel biomarker for lung adenocarcinoma. J. Cell. Biochem. 2020, 121, 3382-3391. [CrossRef] [PubMed]

86. Yang, Y.; Guo, Z.; Chen, W.; Wang, X.; Cao, M.; Han, X.; Zhang, K.; Teng, B.; Cao, J.; Wu, W.; et al. M2 Macrophage-Derived Exosomes Promote Angiogenesis and Growth of Pancreatic Ductal Adenocarcinoma by Targeting E2F2. Mol. Ther 2021, 29, 1226-1238. [CrossRef]

87. Liao, Z.; Chen, Y.; Duan, C.; Zhu, K.; Huang, R.; Zhao, H.; Hintze, M.; Pu, Q.; Yuan, Z.; Lv, L.; et al. Cardiac telocytes inhibit cardiac microvascular endothelial cell apoptosis through exosomal miRNA-21-5p-targeted cdip1 silencing to improve angiogenesis following myocardial infarction. Theranostics 2021, 11, 268-291. [CrossRef] [PubMed]

88. Rezaei, R.; Baghaei, K.; Amani, D.; Piccin, A.; Hashemi, S.M.; Asadzadeh Aghdaei, H.; Zali, M.R. Exosome-mediated delivery of functionally active miRNA-375-3p mimic regulate epithelial mesenchymal transition (EMT) of colon cancer cells. Life Sci. 2021, 269, 119035. [CrossRef]

89. Cai, G.; Cai, G.; Zhou, H.; Zhuang, Z.; Liu, K.; Pei, S.; Wang, Y.; Wang, H.; Wang, X.; Xu, S.; et al. Mesenchymal stem cell-derived exosome miR-542-3p suppresses inflammation and prevents cerebral infarction. Stem Cell Res. Ther. 2021, 12, 2. [CrossRef]

90. Zhou, C.; Wei, W.; Ma, J.; Yang, Y.; Liang, L.; Zhang, Y.; Wang, Z.; Chen, X.; Huang, L.; Wang, W.; et al. Cancer-secreted exosomal miR-1468-5p promotes tumor immune escape via the immunosuppressive reprogramming of lymphatic vessels. Mol. Ther. 2021, 29, 1512-1528. [CrossRef]

91. Luo, T.; Liu, Q.; Tan, A.; Duan, L.; Jia, Y.; Nong, L.; Tang, J.; Zhou, W.; Xie, W.; Lu, Y.; et al. Mesenchymal Stem Cell-Secreted Exosome Promotes Chemoresistance in Breast Cancer via Enhancing miR-21-5p-Mediated S100A6 Expression. Mol. Ther. Oncolytics 2020, 19, 283-293. [CrossRef]

92. Gao, M.; Yu, T.; Liu, D.; Shi, Y.; Yang, P.; Zhang, J.; Wang, J.; Liu, Y.; Zhang, X. Sepsis plasma-derived exosomal miR-1-3p induces endothelial cell dysfunction by targeting SERP1. Clin. Sci. 2021, 135, 347-365. [CrossRef] [PubMed]

93. Gámez-Valero, A.; Campdelacreu, J.; Vilas, D.; Ispierto, L.; Reñé, R.; Álvarez, R.; Armengol, M.P.; Borràs, F.E.; Beyer, K. Exploratory study on microRNA profiles from plasma-derived extracellular vesicles in Alzheimer's disease and dementia with Lewy bodies. Transl. Neurodegener. 2019, 8, 31. [CrossRef] [PubMed]

94. Jia, Y.; Ding, X.; Zhou, L.; Zhang, L.; Yang, X. Mesenchymal stem cells-derived exosomal microRNA-139-5p restrains tumorigenesis in bladder cancer by targeting PRC1. Oncogene 2021, 40, 246-261. [CrossRef]

95. Chen, F.; Xu, B.; Li, J.; Yang, X.; Gu, J.; Yao, X.; Sun, X. Hypoxic tumour cell-derived exosomal miR-340-5p promotes radioresistance of oesophageal squamous cell carcinoma via KLF10. J. Exp. Clin. Cancer Res. 2021, 40, 38. [CrossRef] [PubMed]

96. He, L.; Ping, F.; Fan, Z.; Zhang, C.; Deng, M.; Cheng, B.; Xia, J. Salivary exosomal miR-24-3p serves as a potential detective biomarker for oral squamous cell carcinoma screening. Biomed. Pharmacother. 2020, 121, 109553. [CrossRef] [PubMed]

97. Farag, A.F.; Sabry, D.; Hassabou, N.F.; Alaa El-Din, Y. MicroRNA-134/MicroRNA-200a Derived Salivary Exosomes are Novel Diagnostic Biomarkers of Oral Squamous Cell Carcinoma. Egypt. Dent. J. 2021, 67, 367-377. [CrossRef]

98. Wang, C.; Wang, J.; Cui, W.; Liu, Y.; Zhou, H.; Wang, Y.; Chen, X.; Chen, X.; Wang, Z. Serum Exosomal miRNA-1226 as Potential Biomarker of Pancreatic Ductal Adenocarcinoma. Onco Targets Ther. 2021, 14, 1441-1451. [CrossRef]

99. Guo, X.; Gao, L.; Wang, Y.; Chiu, D.K.Y.; Wang, T.; Deng, Y. Advances in long noncoding RNAs: Identification, structure prediction and function annotation. Brief. Funct. Genom. 2016, 15, 38-46. [CrossRef]

100. Losko, M.; Kotlinowski, J.; Jura, J. Long Noncoding RNAs in Metabolic Syndrome Related Disorders. Mediat. Inflamm. 2016, 2016, 5365209. [CrossRef]

101. Babak, T.; Blencowe, B.J.; Hughes, T.R. A systematic search for new mammalian noncoding RNAs indicates little conserved intergenic transcription. BMC Genom. 2005, 6, 104. [CrossRef]

102. Marques, A.C.; Ponting, C.P. Catalogues of mammalian long noncoding RNAs: Modest conservation and incompleteness. Genome Biol. 2009, 10, R124. [CrossRef]

103. Bermúdez, M.; Aguilar-Medina, M.; Lizárraga-Verdugo, E.; Avendaño-Félix, M.; Silva-Benítez, E.; López-Camarillo, C.; RamosPayán, R. LncRNAs as Regulators of Autophagy and Drug Resistance in Colorectal Cancer. Front. Oncol. 2019, 9, 1008. [CrossRef] [PubMed]

104. Xue, W.-J.; Ying, X.-L.; Jiang, J.-H.; Xu, Y.-H. Prostate cancer antigen 3 as a biomarker in the urine for prostate cancer diagnosis: A meta-analysis. J. Cancer Res. Ther. 2014, 10, C218-C221. [CrossRef] [PubMed]

105. Hu, B.; Yang, H.; Yang, H. Diagnostic value of urine prostate cancer antigen 3 test using a cutoff value of $35 \mu \mathrm{g} / \mathrm{L}$ in patients with prostate cancer. Tumor Biol. 2014, 35, 8573-8580. [CrossRef]

106. Luo, M.; Li, Z.; Wang, W.; Zeng, Y.; Liu, Z.; Qiu, J. Long non-coding RNA H19 increases bladder cancer metastasis by associating with EZH2 and inhibiting E-cadherin expression. Cancer Lett. 2013, 333, 213-221. [CrossRef] 
107. Wang, J.; Yang, K.; Yuan, W.; Gao, Z. Determination of Serum Exosomal H19 as a Noninvasive Biomarker for Bladder Cancer Diagnosis and Prognosis. Med. Sci. Monit. 2018, 24, 9307-9316. [CrossRef] [PubMed]

108. Uszczynska-Ratajczak, B.; Lagarde, J.; Frankish, A.; Guigó, R.; Johnson, R. Towards a complete map of the human long non-coding RNA transcriptome. Nat. Rev. Genet. 2018, 19, 535-548. [CrossRef]

109. Fang, S.; Zhang, L.; Guo, J.; Niu, Y.; Wu, Y.; Li, H.; Zhao, L.; Li, X.; Teng, X.; Sun, X.; et al. NONCODEV5: A comprehensive annotation database for long non-coding RNAs. Nucleic Acids Res. 2018, 46, D308-D314. [CrossRef]

110. Zou, J.; Guo, Y.; Wei, L.; Yu, F.; Yu, B.; Xu, A. Long Noncoding RNA POU3F3 and $\alpha$-Synuclein in Plasma L1CAM Exosomes Combined with $\beta$-Glucocerebrosidase Activity: Potential Predictors of Parkinson's Disease. Neurotherapeutics 2020, 17, 1104-1119. [CrossRef] [PubMed]

111. Wang, Q.; Han, C.-L.; Wang, K.-L.; Sui, Y.-P.; Li, Z.-B.; Chen, N.; Fan, S.-Y.; Shimabukuro, M.; Wang, F.; Meng, F.-G. Integrated analysis of exosomal lncRNA and mRNA expression profiles reveals the involvement of lnc-MKRN2-42:1 in the pathogenesis of Parkinson's disease. CNS Neurosci. Ther. 2020, 26, 527-537. [CrossRef]

112. Dong, A.; Preusch, C.B.; So, W.-K.; Lin, K.; Luan, S.; Yi, R.; Wong, J.W.; Wu, Z.; Cheung, T.H. A long noncoding RNA, LncMyoD, modulates chromatin accessibility to regulate muscle stem cell myogenic lineage progression. Proc. Natl. Acad. Sci. USA 2020, 117, 32464-32475. [CrossRef] [PubMed]

113. Wang, D.; Wang, P.; Bian, X.; Xu, S.; Zhou, Q.; Zhang, Y.; Ding, M.; Han, M.; Huang, L.; Bi, J.; et al. Elevated plasma levels of exosomal BACE1-AS combined with the volume and thickness of the right entorhinal cortex may serve as a biomarker for the detection of Alzheimer's disease. Mol. Med. Rep. 2020, 22, 227-238. [CrossRef]

114. Jiang, Y.; Zhao, H.; Chen, Y.; Li, K.; Li, T.; Chen, J.; Zhang, B.; Guo, C.; Qing, L.; Shen, J.; et al. Exosomal long noncoding RNA HOXD-AS1 promotes prostate cancer metastasis via miR-361-5p/FOXM1 axis. Cell Death Dis. 2021, 12, 1129. [CrossRef] [PubMed]

115. Ni, C.; Fang, Q.-Q.; Chen, W.-Z.; Jiang, J.-X.; Jiang, Z.; Ye, J.; Zhang, T.; Yang, L.; Meng, F.-B.; Xia, W.-J.; et al. Breast cancer-derived exosomes transmit lncRNA SNHG16 to induce CD73+ $\gamma \delta 1$ Treg cells. Signal Transduct. Target. Ther. 2020, 5, 41. [CrossRef] [PubMed]

116. Zang, X.; Gu, J.; Zhang, J.; Shi, H.; Hou, S.; Xu, X.; Chen, Y.; Zhang, Y.; Mao, F.; Qian, H.; et al. Exosome-transmitted lncRNA UFC1 promotes non-small-cell lung cancer progression by EZH2-mediated epigenetic silencing of PTEN expression. Cell Death Dis. 2020, 11, 215. [CrossRef] [PubMed]

117. Zheng, H.; Chen, C.; Luo, Y.; Yu, M.; He, W.; An, M.; Gao, B.; Kong, Y.; Ya, Y.; Lin, Y.; et al. Tumor-derived exosomal BCYRN1 activates WNT5A/VEGF-C/VEGFR3 feedforward loop to drive lymphatic metastasis of bladder cancer. Clin. Transl. Med. 2021, 11, e497. [CrossRef] [PubMed]

118. Chen, C.; Luo, Y.; He, W.; Zhao, Y.; Kong, Y.; Liu, H.; Zhong, G.; Li, Y.; Li, J.; Huang, J.; et al. Exosomal long noncoding RNA LNMAT2 promotes lymphatic metastasis in bladder cancer. J. Clin. Investig. 2020, 130, 404-421. [CrossRef] [PubMed]

119. Wang, L.; Bo, X.; Yi, X.; Xiao, X.; Zheng, Q.; Ma, L.; Li, B. Exosome-transferred LINC01559 promotes the progression of gastric cancer via PI3K/AKT signaling pathway. Cell Death Dis. 2020, 11, 723. [CrossRef]

120. Guo, X.; Lv, X.; Ru, Y.; Zhou, F.; Wang, N.; Xi, H.; Zhang, K.; Li, J.; Chang, R.; Xie, T.; et al. Circulating Exosomal Gastric Cancer-Associated Long Noncoding RNA1 as a Biomarker for Early Detection and Monitoring Progression of Gastric Cancer: A Multiphase Study. JAMA Surg. 2020, 155, 572-579. [CrossRef]

121. Piao, H.Y.; Guo, S.; Wang, Y.; Zhang, J. Exosome-transmitted lncRNA PCGEM1 promotes invasive and metastasis in gastric cancer by maintaining the stability of SNAI1. Clin. Transl. Oncol. 2021, 23, 246-256. [CrossRef]

122. Chen, C.; Shang, A.; Sun, Z.; Gao, Y.; Huang, J.; Ping, Y.; Chang, W.; Gu, C.; Sun, J.; Ji, P.; et al. Urinary Exosomal Long Noncoding RNA TERC as a Noninvasive Diagnostic and Prognostic Biomarker for Bladder Urothelial Carcinoma. J. Immunol. Res. 2022, 2022, 9038808. [CrossRef] [PubMed]

123. Mi, X.; Xu, R.; Hong, S.; Xu, T.; Zhang, W.; Liu, M. M2 Macrophage-Derived Exosomal lncRNA AFAP1-AS1 and MicroRNA-26a Affect Cell Migration and Metastasis in Esophageal Cancer. Mol. Ther. Nucleic Acids 2020, 22, 779-790. [CrossRef] [PubMed]

124. Xia, W.; Chen, H.; Xie, C.; Hou, M. Long-noncoding RNA MALAT1 sponges microRNA-92a-3p to inhibit doxorubicin-induced cardiac senescence by targeting ATG4a. Aging 2020, 12, 8241-8260. [CrossRef] [PubMed]

125. Wang, X.; Pei, X.; Guo, G.; Qian, X.; Dou, D.; Zhang, Z.; Xu, X.; Duan, X. Exosome-mediated transfer of long noncoding RNA H19 induces doxorubicin resistance in breast cancer. J. Cell. Physiol. 2020, 235, 6896-6904. [CrossRef]

126. Wilusz Jeremy, E.; Sharp Phillip, A. A Circuitous Route to Noncoding RNA. Science 2013, 340, 440-441. [CrossRef]

127. Li, L.; Chen, Y.; Nie, L.; Ding, X.; Zhang, X.; Zhao, W.; Xu, X.; Kyei, B.; Dai, D.; Zhan, S.; et al. MyoD-induced circular RNA CDR1as promotes myogenic differentiation of skeletal muscle satellite cells. Biochim. Biophys. Acta BBA Gene Regul. Mech. 2019, 1862, 807-821. [CrossRef] [PubMed]

128. Legnini, I.; Di Timoteo, G.; Rossi, F.; Morlando, M.; Briganti, F.; Sthandier, O.; Fatica, A.; Santini, T.; Andronache, A.; Wade, M.; et al. Circ-ZNF609 Is a Circular RNA that Can Be Translated and Functions in Myogenesis. Mol. Cell 2017, 66, 22-37.e29. [CrossRef]

129. Wang, X.; Cao, X.; Dong, D.; Shen, X.; Cheng, J.; Jiang, R.; Yang, Z.; Peng, S.; Huang, Y.; Lan, X.; et al. Circular RNA TTN Acts As a miR-432 Sponge to Facilitate Proliferation and Differentiation of Myoblasts via the IGF2/PI3K/AKT Signaling Pathway. Mol. Ther. Nucleic Acids 2019, 18, 966-980. [CrossRef] 
130. Zheng, S.; Zhang, X.; Odame, E.; Xu, X.; Chen, Y.; Ye, J.; Zhou, H.; Dai, D.; Kyei, B.; Zhan, S.; et al. CircRNA-Protein Interactions in Muscle Development and Diseases. Int. J. Mol. Sci. 2021, 22, 3262. [CrossRef]

131. Pandey, P.R.; Yang, J.-H.; Tsitsipatis, D.; Panda, A.C.; Noh, J.H.; Kim, K.M.; Munk, R.; Nicholson, T.; Hanniford, D.; Argibay, D.; et al. circSamd4 represses myogenic transcriptional activity of PUR proteins. Nucleic Acids Res. 2020, 48, 3789-3805. [CrossRef]

132. He, J.; Xie, Q.; Xu, H.; Li, J.; Li, Y. Circular RNAs and cancer. Cancer Lett. 2017, 396, 138-144. [CrossRef] [PubMed]

133. Hansen, T.B.; Kjems, J.; Damgaard, C.K. Circular RNA and miR-7 in Cancer. Cancer Res. 2013, 73, 5609. [CrossRef] [PubMed]

134. Zhao, Z.; Wang, K.; Wu, F.; Wang, W.; Zhang, K.; Hu, H.; Liu, Y.; Jiang, T. circRNA disease: A manually curated database of experimentally supported circRNA-disease associations. Cell Death Dis. 2018, 9, 475. [CrossRef] [PubMed]

135. Verduci, L.; Tarcitano, E.; Strano, S.; Yarden, Y.; Blandino, G. CircRNAs: Role in human diseases and potential use as biomarkers. Cell Death Dis. 2021, 12, 468. [CrossRef] [PubMed]

136. Harland, R.; Misher, L. Stability of RNA in developing Xenopus embryos and identification of a destabilizing sequence in TFIIIA messenger RNA. Development 1988, 102, 837-852. [CrossRef]

137. Danan, M.; Schwartz, S.; Edelheit, S.; Sorek, R. Transcriptome-wide discovery of circular RNAs in Archaea. Nucleic Acids Res. 2012, 40, 3131-3142. [CrossRef]

138. He, J.; Ren, M.; Li, H.; Yang, L.; Wang, X.; Yang, Q. Exosomal Circular RNA as a Biomarker Platform for the Early Diagnosis of Immune-Mediated Demyelinating Disease. Front. Genet. 2019, 10, 860. [CrossRef]

139. Li, Y.; Zheng, Q.; Bao, C.; Li, S.; Guo, W.; Zhao, J.; Chen, D.; Gu, J.; He, X.; Huang, S. Circular RNA is enriched and stable in exosomes: A promising biomarker for cancer diagnosis. Cell Res. 2015, 25, 981-984. [CrossRef]

140. Chen, W.; Quan, Y.; Fan, S.; Wang, H.; Liang, J.; Huang, L.; Chen, L.; Liu, Q.; He, P.; Ye, Y. Exosome-transmitted circular RNA hsa_circ_0051443 suppresses hepatocellular carcinoma progression. Cancer Lett. 2020, 475, 119-128. [CrossRef]

141. Yang, H.; Zhang, H.; Yang, Y.; Wang, X.; Deng, T.; Liu, R.; Ning, T.; Bai, M.; Li, H.; Zhu, K.; et al. Hypoxia induced exosomal circRNA promotes metastasis of Colorectal Cancer via targeting GEF-H1/RhoA axis. Theranostics 2020, 10, 8211-8226. [CrossRef]

142. Dou, Y.-Q.; Kong, P.; Li, C.-L.; Sun, H.-X.; Li, W.-W.; Yu, Y.; Nie, L.; Zhao, L.-L.; Miao, S.-B.; Li, X.-K.; et al. Smooth muscle SIRT1 reprograms endothelial cells to suppress angiogenesis after ischemia. Theranostics 2020, 10, 1197-1212. [CrossRef]

143. Sun, R.; Liu, W.; Zhao, Y.; Chen, H.; Wang, Z.; Zhang, Y.; Sun, X.; Cui, X. Exosomal circRNA as a novel potential therapeutic target for multiple myeloma-related myocardial damage. Cancer Cell Int. 2021, 21, 311. [CrossRef]

144. Xiong, L.; Chen, L.; Wu, L.; He, W.; Chen, D.; Peng, Z.; Li, J.; Zhu, X.; Su, L.; Li, Y.; et al. Lipotoxicity-induced circGlis3 impairs beta cell function and is transmitted by exosomes to promote islet endothelial cell dysfunction. Diabetologia 2022, 65, 188-205. [CrossRef] [PubMed]

145. Lu, J.; Wang, Y.-H.; Yoon, C.; Huang, X.-Y.; Xu, Y.; Xie, J.-W.; Wang, J.-B.; Lin, J.-x.; Chen, Q.-Y.; Cao, L.-L.; et al. Circular RNA circ-RanGAP1 regulates VEGFA expression by targeting miR-877-3p to facilitate gastric cancer invasion and metastasis. Cancer Lett. 2020, 471, 38-48. [CrossRef]

146. Huang, X.-Y.; Huang, Z.-L.; Huang, J.; Xu, B.; Huang, X.-Y.; Xu, Y.-H.; Zhou, J.; Tang, Z.-Y. Exosomal circRNA-100338 promotes hepatocellular carcinoma metastasis via enhancing invasiveness and angiogenesis. J. Exp. Clin. Cancer Res. 2020, 39, 20. [CrossRef] [PubMed]

147. He, F.; Zhong, X.; Lin, Z.; Lin, J.; Qiu, M.; Li, X.; Hu, Z. Plasma exo-hsa_circRNA_0056616: A potential biomarker for lymph node metastasis in lung adenocarcinoma. J. Cancer 2020, 11, 4037-4046. [CrossRef] [PubMed]

148. Wu, G.; Zhou, W.; Pan, X.; Sun, Z.; Sun, Y.; Xu, H.; Shi, P.; Li, J.; Gao, L.; Tian, X. Circular RNA Profiling Reveals Exosomal circ_0006156 as a Novel Biomarker in Papillary Thyroid Cancer. Mol. Ther Nucleic Acids 2020, 19, 1134-1144. [CrossRef] [PubMed]

149. Li, P.; Xu, Z.; Liu, T.; Liu, Q.; Zhou, H.; Meng, S.; Feng, Z.; Tang, Y.; Liu, C.; Feng, J.; et al. Circular RNA Sequencing Reveals Serum Exosome Circular RNA Panel for High-Grade Astrocytoma Diagnosis. Clin. Chem. 2021, 68, hvab254. [CrossRef]

150. Tian, C.; Liu, J.; Di, X.; Cong, S.; Zhao, M.; Wang, K. Exosomal hsa_circRNA_104484 and hsa_circRNA_104670 may serve as potential novel biomarkers and therapeutic targets for sepsis. Sci. Rep. 2021, 11, 14141. [CrossRef]

151. Yu, M.; Yu, J.; Zhang, Y.; Sun, X.; Sun, R.; Xia, M.; Li, S.; Cui, X. A novel circRNA-miRNA-mRNA network revealed exosomal circ-ATP10A as a biomarker for multiple myeloma angiogenesis. Bioengineered 2022, 13, 667-683. [CrossRef]

152. Zhong, A.-N.; Yin, Y.; Tang, B.-J.; Chen, L.; Shen, H.-W.; Tan, Z.-P.; Li, W.-Q.; He, Q.; Sun, B.; Zhu, Y.; et al. CircRNA Microarray Profiling Reveals hsa_circ_0058493 as a Novel Biomarker for Imatinib-Resistant CML. Front. Pharmacol. 2021, 12, 2479. [CrossRef] [PubMed]

153. Pan, Z.; Zhao, R.; Li, B.; Qi, Y.; Qiu, W.; Guo, Q.; Zhang, S.; Zhao, S.; Xu, H.; Li, M.; et al. EWSR1-induced circNEIL3 promotes glioma progression and exosome-mediated macrophage immunosuppressive polarization via stabilizing IGF2BP3. Mol. Cancer 2022, 21, 16. [CrossRef]

154. Yang, D.; Zhang, W.; Zhang, H.; Zhang, F.; Chen, L.; Ma, L.; Larcher, L.M.; Chen, S.; Liu, N.; Zhao, Q.; et al. Progress, opportunity, and perspective on exosome isolation-Efforts for efficient exosome-based theranostics. Theranostics 2020, 10, 3684-3707. [CrossRef] [PubMed]

155. Lee, H.; Zhang, D.; Zhu, Z.; Dela Cruz, C.S.; Jin, Y. Epithelial cell-derived microvesicles activate macrophages and promote inflammation via microvesicle-containing microRNAs. Sci. Rep. 2016, 6, 35250. [CrossRef]

156. Raposo, G.; Nijman, H.W.; Stoorvogel, W.; Liejendekker, R.; Harding, C.V.; Melief, C.J.; Geuze, H.J. B lymphocytes secrete antigen-presenting vesicles. J. Exp. Med. 1996, 183, 1161-1172. [CrossRef] [PubMed] 
157. Muller, L.; Hong, C.-S.; Stolz, D.B.; Watkins, S.C.; Whiteside, T.L. Isolation of biologically-active exosomes from human plasma. J. Immunol. Methods 2014, 411, 55-65. [CrossRef] [PubMed]

158. Hiemstra, T.F.; Charles, P.D.; Gracia, T.; Hester, S.S.; Gatto, L.; Al-Lamki, R.; Floto, R.A.; Su, Y.; Skepper, J.N.; Lilley, K.S.; et al. Human Urinary Exosomes as Innate Immune Effectors. J. Am. Soc. Nephrol. 2014, 25, 2017. [CrossRef]

159. Livshits, M.A.; Khomyakova, E.; Evtushenko, E.G.; Lazarev, V.N.; Kulemin, N.A.; Semina, S.E.; Generozov, E.V.; Govorun, V.M. Isolation of exosomes by differential centrifugation: Theoretical analysis of a commonly used protocol. Sci. Rep. 2015, 5, 17319. [CrossRef]

160. Bano, R.; Ahmad, F.; Mohsin, M. A perspective on the isolation and characterization of extracellular vesicles from different biofluids. RSC Adv. 2021, 11, 19598-19615. [CrossRef]

161. Cvjetkovic, A.; Lötvall, J.; Lässer, C. The influence of rotor type and centrifugation time on the yield and purity of extracellular vesicles. J. Extracell. Vesicles 2014, 3, 23111. [CrossRef]

162. Zhang, M.; Jin, K.; Gao, L.; Zhang, Z.; Li, F.; Zhou, F.; Zhang, L. Methods and Technologies for Exosome Isolation and Characterization. Small Methods 2018, 2, 1800021. [CrossRef]

163. Théry, C.; Ostrowski, M.; Segura, E. Membrane vesicles as conveyors of immune responses. Nat. Rev. Immunol. 2009, 9, 581-593. [CrossRef] [PubMed]

164. Konoshenko, M.Y.; Lekchnov, E.A.; Vlassov, A.V.; Laktionov, P.P. Isolation of Extracellular Vesicles: General Methodologies and Latest Trends. BioMed Res. Int. 2018, 2018, 8545347. [CrossRef] [PubMed]

165. Carnino, J.M.; Lee, H.; Jin, Y. Isolation and characterization of extracellular vesicles from Broncho-alveolar lavage fluid: A review and comparison of different methods. Respir. Res. 2019, 20, 240. [CrossRef] [PubMed]

166. Andreu, Z.; Yáñez-Mó, M. Tetraspanins in extracellular vesicle formation and function. Front. Immunol. 2014, 5, 442. [CrossRef]

167. Liu, C.; Su, C. Design strategies and application progress of therapeutic exosomes. Theranostics 2019, 9, 1015-1028. [CrossRef]

168. Kowal, J.; Arras, G.; Colombo, M.; Jouve, M.; Morath, J.P.; Primdal-Bengtson, B.; Dingli, F.; Loew, D.; Tkach, M.; Théry, C. Proteomic comparison defines novel markers to characterize heterogeneous populations of extracellular vesicle subtypes. Proc. Natl. Acad. Sci. USA 2016, 113, E968-E977. [CrossRef]

169. Tong, C.; Chen, Q.; Zhao, L.; Ma, J.; Ibeagha-Awemu, E.M.; Zhao, X. Identification and characterization of long intergenic noncoding RNAs in bovine mammary glands. BMC Genom. 2017, 18, 468. [CrossRef]

170. Sidhom, K.; Obi, P.O.; Saleem, A. A Review of Exosomal Isolation Methods: Is Size Exclusion Chromatography the Best Option? Int. J. Mol. Sci. 2020, 21, 6466. [CrossRef]

171. McNamara, R.P.; Caro-Vegas, C.P.; Costantini, L.M.; Landis, J.T.; Griffith, J.D.; Damania, B.A.; Dittmer, D.P. Large-scale, cross-flow based isolation of highly pure and endocytosis-competent extracellular vesicles. J. Extracell. Vesicles 2018, 7, 1541396. [CrossRef]

172. Merchant, M.L.; Powell, D.W.; Wilkey, D.W.; Cummins, T.D.; Deegens, J.K.; Rood, I.M.; McAfee, K.J.; Fleischer, C.; Klein, E.; Klein, J.B. Microfiltration isolation of human urinary exosomes for characterization by MS. Proteom. Clin. Appl. 2010, 4, 84-96. [CrossRef] [PubMed]

173. Lucchetti, D.; Fattorossi, A.; Sgambato, A. Extracellular Vesicles in Oncology: Progress and Pitfalls in the Methods of Isolation and Analysis. Biotechnol. J. 2019, 14, 1700716. [CrossRef] [PubMed]

174. Zeringer, E.; Barta, T.; Li, M.; Vlassov, A.V. Strategies for isolation of exosomes. Cold Spring Harb. Protoc. 2015, $2015,319-323$. [CrossRef] [PubMed]

175. Doyle, L.M.; Wang, M.Z. Overview of Extracellular Vesicles, Their Origin, Composition, Purpose, and Methods for Exosome Isolation and Analysis. Cells 2019, 8, 727. [CrossRef]

176. Gámez-Valero, A.; Monguió-Tortajada, M.; Carreras-Planella, L.; Franquesa, M.l.; Beyer, K.; Borràs, F.E. Size-Exclusion Chromatography-based isolation minimally alters Extracellular Vesicles' characteristics compared to precipitating agents. Sci. Rep. 2016, 6, 33641. [CrossRef]

177. Gheinani, A.H.; Vögeli, M.; Baumgartner, U.; Vassella, E.; Draeger, A.; Burkhard, F.C.; Monastyrskaya, K. Improved isolation strategies to increase the yield and purity of human urinary exosomes for biomarker discovery. Sci. Rep. 2018, 8, 3945. [CrossRef]

178. Guerreiro, E.M.; Vestad, B.; Steffensen, L.A.; Aass, H.C.D.; Saeed, M.; Øvstebø, R.; Costea, D.E.; Galtung, H.K.; Søland, T.M. Efficient extracellular vesicle isolation by combining cell media modifications, ultrafiltration, and size-exclusion chromatography. PLoS ONE 2018, 13, e0204276. [CrossRef]

179. Soares Martins, T.; Catita, J.; Martins Rosa, I.; Da Cruz Silva, O.A.B.E.; Henriques, A.G. Exosome isolation from distinct biofluids using precipitation and column-based approaches. PLoS ONE 2018, 13, e0198820. [CrossRef]

180. García-Romero, N.; Madurga, R.; Rackov, G.; Palacín-Aliana, I.; Núñez-Torres, R.; Asensi-Puig, A.; Carrión-Navarro, J.; EstebanRubio, S.; Peinado, H.; González-Neira, A.; et al. Polyethylene glycol improves current methods for circulating extracellular vesicle-derived DNA isolation. J. Transl. Med. 2019, 17, 75. [CrossRef]

181. Samsonov, R.; Shtam, T.; Burdakov, V.; Glotov, A.; Tsyrlina, E.; Berstein, L.; Nosov, A.; Evtushenko, V.; Filatov, M.; Malek, A. Lectin-induced agglutination method of urinary exosomes isolation followed by mi-RNA analysis: Application for prostate cancer diagnostic. Prostate 2016, 76, 68-79. [CrossRef]

182. Salieb-Beugelaar, G.B.; Simone, G.; Arora, A.; Philippi, A.; Manz, A. Latest Developments in Microfluidic Cell Biology and Analysis Systems. Anal. Chem. 2010, 82, 4848-4864. [CrossRef] [PubMed] 
183. Jackson, E.L.; Lu, H. Advances in microfluidic cell separation and manipulation. Curr. Opin. Chem. Eng. 2013, 2, 398-404. [CrossRef] [PubMed]

184. Gholizadeh, S.; Shehata Draz, M.; Zarghooni, M.; Sanati-Nezhad, A.; Ghavami, S.; Shafiee, H.; Akbari, M. Microfluidic approaches for isolation, detection, and characterization of extracellular vesicles: Current status and future directions. Biosens. Bioelectron. 2017, 91, 588-605. [CrossRef] [PubMed]

185. Chen, C.; Skog, J.; Hsu, C.-H.; Lessard, R.T.; Balaj, L.; Wurdinger, T.; Carter, B.S.; Breakefield, X.O.; Toner, M.; Irimia, D. Microfluidic isolation and transcriptome analysis of serum microvesicles. Lab Chip 2010, 10, 505-511. [CrossRef] 